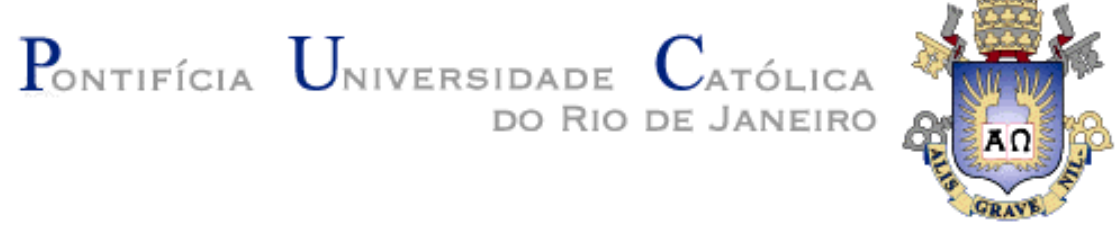

Isadora de Oliveira Lima Tostes

\title{
Pulsão de morte: destruição e criação
}

Dissertação de Mestrado

Dissertação apresentada como requisito parcial para obtenção do grau de Mestre pelo Programa de Pós Graduação em Psicologia (Psicologia Clínica) do Departamento de Psicologia do Centro de Teologia e Ciências Humanas da PUC-Rio.

Orientadora: Profa. Monah Winograd

Rio de Janeiro

Fevereiro de 2017 


\title{
Isadora de Oliveira Lima Tostes
}

\author{
Pulsão de morte: destruição e \\ criação
}

\begin{abstract}
Dissertação apresentada como requisito parcial para obtenção do grau de Mestre pelo Programa de PósGraduação em Psicologia (Psicologia Clínica) do Departamento de Psicologia do Centro de Teologia e Ciências Humanas da PUC-Rio. Aprovada pela Comissão Examinadora abaixo assinada.
\end{abstract}

Profa. Monah Winograd

Orientadora

Departamento de Psicologia - PUC-Rio

Profa. Claudia Amorim Garcia

Departamento de Psicologia - PUC-Rio

Prof. Julio Sergio Verztman

Instituto de Psiquiatria - UFRJ

Profa. Monah Winograd

Coordenadora Setorial de Pós-Graduação

e Pesquisa do Centro de Teologia

e Ciências Humanas - PUC-Rio

Rio de Janeiro, 28 de março de 2017. 
Todos os direitos reservados. É proibida a reprodução total ou parcial do trabalho sem autorização da universidade, da autora e do orientador.

\section{Isadora de Oliveira Lima Tostes}

Graduou-se em Psicologia na PUC-Rio em 2014.

Ficha Catalográfica

Tostes, Isadora de Oliveira Lima

Pulsão de morte : destruição e criação / Isadora de Oliveira Lima Tostes ; orientadora: Monah Winograd. - 2017. 92 f. ; $30 \mathrm{~cm}$

Dissertação (mestrado)-Pontifícia Universidade Católica do Rio de Janeiro, Departamento de Psicologia, 2017. Inclui bibliografia

1. Psicologia - Teses. 2. Pulsão de morte. 3. Trabalho do negativo. 4. Constituição psíquica. I. Winograd, Monah. II. Pontifícia Universidade Católica do Rio de Janeiro. Departamento de Psicologia. III. Título. 


\section{Agradecimentos}

À Capes e à PUC-Rio, pelos incentivos concedidos, sem os quais este trabalho não poderia ter sido realizado.

À minha orientadora Monah Winograd, por esta oportunidade, pelo exemplo, pela parceria e pelo acolhimento durante estes dois anos.

À Barbara Andrade e à Perla Klautau, pela inspiração e pelas trocas.

Aos professores da comissão examinadora, Claudia Garcia e Julio Verztman, por terem aceitado meu convite e por contribuírem com a minha pesquisa.

À Isabel Fortes, pela disponibilidade.

À Marcelina, pela paciência com que ouviu todas as minhas dúvidas.

Aos meus pais, José Eduardo e Andrea, pelo apoio em todas as minhas decisões, pelo interesse no meu trabalho e pela compreensão nos momentos difíceis.

Aos meus irmãos Eduardo, Natalia, Paula e Juliana, por me escutarem e por terem sido o suporte e o conforto de onde tirei as forças.

Às minhas amigas quase irmãs Luiza, Isabel e Julia, pela atenção, pelas palavras de incentivo e carinho durante todo o processo, e por terem compreendido meus muitos momentos de ausência.

À Deborah, Lis e Júlia, pela forma sempre sensível e cuidadosa com que incentivam, acompanham e torcem pelos meus projetos.

À Alice e à Sylvia, companheiras desta caminhada, que compartilharam comigo tantos momentos de angústia e alegria intensas, e sem cujo apoio este trabalho não teria sido possível.

Ao Ricardo, pela leitura cuidadosa e pela constante presença, mesmo quando ausente.

Ao Pedro Salem, cuja escuta e acolhimento foram tão importantes durante todo o processo de escrita. 


\section{Resumo}

Tostes, Isadora de Oliveira Lima; Winograd, Monah (Orientadora). Pulsão de morte: destruição e criação. Rio de Janeiro, 2017. 92p. Dissertação de Mestrado - Departamento de Psicologia, Pontifícia Universidade Católica do Rio de Janeiro.

A presente dissertação pretende investigar o paradoxo da pulsão de morte: se, por um lado, os movimentos destrutivos que esta coloca em ação são claramente observados na clínica psicanalítica, por outro, nos interessa apontar a possibilidade de criação que a mesma propicia ao desfazer as ligações já estabelecidas, colocando o psiquismo frente ao irrepresentável que o movimenta. Para tanto, estudaremos o trabalho do negativo, tendo em vista que essa teorização nos permite examinar a ação da pulsão de morte em sua face estruturante e em sua face desestruturante do aparato psíquico. No que se refere a sua ação desorganizadora, pensaremos os efeitos patológicos da ação da pulsão de morte como efeitos colaterais de uma tentativa radical de sobrevivência a um objeto primário absoluto, portanto, como um esforço de subjetivação.

\section{Palavras-chave}

Pulsão de morte; trabalho do negativo; constituição psíquica. 


\section{Abstract}

Tostes, Isadora de Oliveira Lima; Winograd, Monah (Advisor). Death drive: destruction and creation. Rio de Janeiro, 2017. 92p. Dissertação de Mestrado - Departamento de Psicologia, Pontifícia Universidade Católica do Rio de Janeiro.

The present dissertation aims to investigate the paradox of the death drive: the destructive movements that are put into action are clearly observed in the psychoanalytic clinic, but in contrast we point out the possibility of creation that it facilitates by undoing what is already established, placing the psyche in front of the unrepresentable that makes it move. Therefore, we will study the work of the negative in view that this theorization allows us to examine the action of the death drive in its structuring perspective and in its deconstructing view of the psychic apparatus. With regard to their disorganizing action, we will think of the pathological effects of the death drive as the side effects of a radical attempt to survive an absolute primary object, therefore, as an effort of subjectivation.

\section{Keywords}

Death drive; work of the negative; psychic constitution. 


\section{Sumário}

1. Introdução 09

2. A pulsão de morte em Freud 15

2.1 O conceito de pulsão e a primeira teoria pulsional 15

2.2 A não dominância do princípio de prazer 18

2.3 As neuroses traumáticas: um novo paradigma de trauma 22

2.4 A compulsão à repetição e a segunda teoria pulsional $\quad 26$

2.5 O lugar do irrepresentável na psicanálise 33

2.6 A negativa: a pulsão de morte como constitutiva do psiquismo 36

3. O trabalho do negativo estruturante 41

3.1 A pulsão de morte como motor do trabalho do negativo 42

$3.2 \mathrm{O}$ duplo limite 47

3.3 A função constituinte do "objeto absolutamente necessário" 54

3.4 Alucinação negativa e estrutura enquadrante 59

4. $O$ fracasso do trabalho do negativo e a pulsão de morte como $\begin{array}{ll}\text { protesto vital } & 64\end{array}$

4.1 O objeto absoluto $\quad 65$

4.2 Clivagem radical e a instabilidade do duplo limite $\quad 70$

4.3 Compulsão à repetição e desinvestimento 75

4.4 Protesto vital $\quad 80$

5. Considerações finais 85

6. Referências Bibliográficas 89 
Não nos provoca riso o amor quando chega ao mais profundo de sua viagem, ao mais alto de seu vôo: no mais profundo, no mais alto, nos arranca gemidos $e$ suspiros, vozes de dor, embora seja dor jubilosa, e pensando bem não há nada de estranho nisso, porque nascer é uma alegria que dói. Pequena morte, chamam na França a culminação do abraço, que ao quebrar-nos faz por juntar-nos, e perdendonos faz por nos encontrar e acabando conosco nos principia. Pequena morte, dizem; mas grande, muito grande haverá de ser, se ao nos matar nos nasce.

Eduardo Galeano, A pequena morte 


\section{1 \\ Introdução}

No presente trabalho, pretendemos estudar o conceito de pulsão de morte, mais especificamente no que se refere ao aparente paradoxo que o conceito apresenta, uma vez que podemos conceber esta pulsão tanto como tendo efeitos destrutivos quanto como sendo o que possibilita a criação, justamente pela destruição das formas já instituídas. O interesse sobre este tema advém da monografia de conclusão do curso de Psicologia, trabalho no qual foi estudada a articulação entre os conceitos de repetição e trauma. Durante a realização do primeiro trabalho, o conceito de pulsão de morte apareceu como grande dificuldade e desafio, e muitas questões que não puderam ser aprofundadas naquele momento partiram deste conceito, dentre elas o papel da pulsão de morte na constituição ou na desorganização psíquicas.

O que se coloca, portanto, como tema de partida para a pesquisa a ser realizada é o conceito de pulsão de morte e sua dupla face: se, por um lado, a pulsão de morte está relacionada à manifestações claramente destrutivas e patológicas observadas, sobretudo, nos casos limite, por outro lado podemos observar, a partir dos movimentos disjuntivos que propicia, a fundamental ação dessa mesma pulsão na criação de novas formas dentro do aparato psíquico, e mesmo como condição de possibilidade da própria constituição psíquica. Além disso, nos interessa pensar se, mesmo nas situações em que seus efeitos são inegavelmente patológicos, não poderíamos pensá-los como efeitos colaterais de uma tentativa última e radical de subjetivação e sobrevivência psíquica? (De Oliveira \& Winograd \& Fortes, 2016). Apresenta-se, dessa forma, a aparente dupla face do conceito de pulsão de morte: seria este desorganizador ou constitutivo do psiquismo?

Como nos interessa pensar o paradoxo da pulsão de morte em relação à estruturação psíquica, recorreremos à teorização de André Green (1983/1988, 1993/2010) sobre o trabalho do negativo, uma vez que, a partir deste conceito,

poderemos estudar a ação da pulsão de morte e os movimentos que esta promove tanto no sentido da estruturação quanto no sentido da desorganização do psiquismo. Para tanto, iniciaremos nosso percurso teórico na postulação do 
conceito em Freud (1920/2006), e seguiremos algumas mudanças que sua teorização sofreu ao longo da obra freudiana $(1923,1925,1930)$, na tentativa de abarcar a complexidade do conceito, bem como de encontrar os pontos teóricos nos quais o pensamento de André Green (1993/2010) foi inspirado.

Portanto, no primeiro capítulo partiremos da definição de pulsão (Freud, 1915/2006), conceito que foi desde o início um dos norteadores da teoria psicanalítica, e do primeiro dualismo pulsional a fim de elucidar as questões que resultaram na necessidade de elaboração de um novo e segundo dualismo pulsional. Apresentaremos, dessa forma, os problemas teóricos advindos da clínica que expressavam um tipo de funcionamento psíquico de uma ordem diferente da pulsão sexual. Isto significa que a experiência clínica defrontou os analistas da época com quadros diferentes dos apresentados pelas neuroses clássicas, estas passíveis de serem explicadas pelo conflito entre a pulsão de autoconservação e a pulsão sexual. As neuroses traumáticas, no entanto, apresentavam uma lógica radicalmente diferente desta, e o mecanismo defensivo da compulsão à repetição levou Freud (1920/2006) a repensar tanto a sua concepção sobre o trauma quanto sobre o funcionamento psíquico. Dentro deste novo contexto, a pulsão de morte é postulada para dar conta das manifestações que não podiam ser explicadas pela lógica da sexualidade e da busca de obtenção do prazer. A partir disso, tanto o dualismo pulsional quanto a tópica do aparelho psíquico são reformuladas.

Neste primeiro capítulo procuraremos discutir algumas concepções freudianas sobre a pulsão de morte: desde sua postulação neste momento de questionamentos em 1920, quando Freud a define como tendência de retorno ao inorgânico e, portanto, de redução das tensões do aparato, mas discutiremos também as formulações que se seguiram a esse momento inicial e que serão importantes para pensarmos a pulsão de morte na estruturação psíquica. Dessa forma, percorreremos o Ego e o Id (Freud, 1923/2006), artigo em que, além de uma nova tópica, Freud identifica a ação disjuntiva da pulsão de morte e a importância desse processo disjuntivo na criação de novas formas; o Mal Estar na Civilização (Freud, 1930/2006), a partir do qual é caracterizada a autonomia da pulsão de morte em relação à pulsão sexual, o que implica que ambas apresentam energias diferentes; e, finalmente, A Negativa (Freud, 1925/2006) que, embora curto, é de fundamental importância, uma vez que coloca a pulsão 
de morte no centro da diferenciação entre interior e exterior e, portanto, como essencial na constituição subjetiva. Além de sua importância dentro da teorização freudiana, o artigo A Negativa (Freud, 1925) já justifica, de acordo com Green (1993/2010), toda a necessidade de teorização sobre o trabalho do negativo.

Ainda no âmbito do primeiro capítulo, veremos como, além de uma nova concepção sobre o trauma e uma segunda tópica do aparato psíquico, a pulsão de morte, caracterizada por sua energia livre, possibilita que o irrepresentável seja pensado na psicanálise. Teoricamente, podemos ver efeitos tanto estruturantes quanto desestruturantes do psiquismo frente a essa energia desligada, uma vez que, diante do excesso não representado, o aparato psíquico pode buscar recursos e trabalhar na construção de novas representações ou no remanejamento das representações já existentes e construir um sentido, acolhendo o diferente e produzindo novas formas, ou, num efeito contrário, diante de tal pulsionalidade o psiquismo pode se desorganizar, seja por não ter capacidades suficientes de metabolização, seja pela intensidade da excitação. É a partir desse ponto que poderemos associar o trabalho do negativo à pulsão de morte, uma vez que esta o movimenta, e tal trabalho pode representar, por um lado, a condição de possibilidade da criação, por outro, a impossibilidade de qualquer criação (Green, 1993/2010).

Já no segundo capítulo, trataremos o trabalho do negativo em seu aspecto estruturante, qual seja, a constituição do psiquismo. Veremos como a função desobjetalizante, efeito da ação da pulsão de morte, é fundamental na delimitação das fronteiras do aparato psíquico e na diferenciação entre o mundo interno e o mundo externo, diferenciação essa que precisa ser construída, não estando presente desde o nascimento. Este estabelecimento dos limites do próprio psiquismo, limite objetivo/subjetivo e limite entre as instâncias psíquicas, caracteriza o duplo limite (Green, 1982/2003) e é concomitante à separação entre a criança e a mãe, estando este estabelecimento intimamente ligado à relação com o objeto materno.

Dessa forma, falar em trabalho do negativo estruturante significa abarcar a dimensão da relação com o objeto. No segundo capítulo, portanto, estudaremos a função constituinte que o objeto primário apresenta na constituição psíquica do sujeito e em sua possível individuação. Para isso, é 
preciso que o objeto forneça uma presença segura e constante que seja capaz de estimular, conter e dar algum significado à pulsionalidade da criança, ao mesmo tempo que suportando seus ataques e devolvendo os conteúdos desprazerosos de forma suportável. Esse objeto primário deve ainda ser capaz de frustrar as demandas da criança e de se ausentar por alguns momentos. A frustração permitirá que a criança comece a distinguir seu mundo interno da realidade externa. Por sua vez, a ausência, se experienciada como presença em potencial, o que significa que a criança tem a confiança de que o objeto pode voltar, possibilitará a construção da estrutura enquadrante, espaço psíquico pessoal a partir do qual se darão os processos de representação, o que promoverá os processos de pensamento e até mesmo a capacidade de desejar.

O estabelecimento da estrutura enquadrante é uma apropriação do objeto materno que constitui o indivíduo e permite, dessa forma, que outros objetos substitutos sejam escolhidos na busca pela satisfação. O movimento de separação mãe/bebê bem sucedido implica que a pulsão de morte esteja ativa em ambos, o que possibilita a individuação do sujeito e toda a emergência dos processos de representação, de ligação, de pensamento e simbolização. Dessa forma, o trabalho do negativo, ação da pulsão de morte, promove as possibilidades infinitas de que o psiquismo pode ser capaz, resultando numa estruturação saudável do aparato psíquico. No entanto, toda a potencialidade traumática e destrutiva da pulsão de morte pode ser manifestada nos casos em que este trabalho do negativo fracassa e se transforma, portanto, em desestruturante e desorganizador do aparato psíquico.

No terceiro capítulo, nos debruçaremos, portanto, sobre o trabalho do negativo em sua face desestruturante. Aqui, a função desobjetalizante da pulsão de morte, que pode trabalhar no sentido da disjunção exigida no momento de separação mãe/bebê, atinge toda sua radicalidade na busca do narcisismo negativo, qual seja, de atingir o zero de tensão dentro do aparato psíquico (Green, 1983/1988). Assim, da mesma forma que o estabelecimento dos limites psíquicos e a constituição da estrutura enquadrante estão associados à relação com o objeto primário, a sintomatologia decorrente do fracasso do trabalho do negativo e a consequente preponderância da pulsão de morte são também efeitos de uma relação com o objeto materno, que aqui falhou em cumprir suas funções. 
A fim de analisar as manifestações do trabalho do negativo desestruturante, precisaremos abordar a relação com um objeto primário que não conseguiu cumprir as funções que seriam necessárias no momento de constituição psíquica, não se colocando, portanto, como auxiliar do ego da criança. É preciso ressaltar que tanto um objeto que esteve muito presente quanto um objeto que se fez ausente demais não podem cumprir suas funções, uma vez que se apresentam, de um modo ou de outro, como excessivos e, por isso, traumáticos. Dessa forma, o objeto não possibilita a contenção e significação da pulsão, mas, ao contrário, a torna insuportável. Como o registro da ausência não pode se dar em nenhum dos casos, o sujeito não consegue estabelecer a confiança necessária para que consiga perder o objeto primário, que se torna, assim, absoluto. O indivíduo fica preso e paralisado diante da impossibilidade de perder este objeto, o que provoca uma dupla angústia: tanto a de ser invadido quanto a de perder o objeto de amor, cuja relação o sujeito tenta manter a qualquer custo. Deste modo, não é possível escolher objetos que substituam o objeto materno absoluto.

O fracasso do trabalho do negativo implica que a separação mãe/bebê, que é individualizante, não ocorreu de forma completa, o que apresenta diversas consequências. Em primeiro lugar, pode-se observar a frágil constituição dos limites egóicos, o que prejudica a capacidade de elaboração e de pensamento. Tendo isso em vista, abordaremos três formas de defesa utilizadas pelo sujeito para lidar com esse traumático que ameaça sua integridade egóica: o mecanismo de clivagem, a compulsão à repetição e o desinvestimento excessivo. Estas são três formas radicais que o indivíduo encontra não só para se defender, mas para sobreviver.

No entanto, por mais que não possamos negar ou ignorar os efeitos patológicos que tais mecanismos de defesa apresentam, nos interessa pensar na possível tentativa de subjetivação que eles implicam. Estas defesas se apresentam, na realidade, como formas encontradas para existir apesar do traumático acachapante. Deste modo, ainda no capítulo três, apresentaremos a interpretação de Zaltzman (1994) sobre o conceito de pulsão de morte, uma vez que a autora aponta esta pulsão como o que movimenta um último protesto a favor da vida. Afirmando que o excesso de pulsão de vida pode também trazer efeitos patológicos, a autora defende que, em algumas situações específicas, 
somente a energia da pulsão de morte pode funcionar como tentativa última de sobrevivência e insistência na vida (Zaltzman, 1994).

Através do percurso teórico que acabamos de descrever, portanto, pretendemos estudar o conceito de pulsão de morte e apresentá-lo, desde Freud (1920/2006, 1925/2006) e em parte da teorização de André Green (1983/1988, 1993/2010) em seus possíveis efeitos tanto criativos e estruturantes do psiquismo quanto desorganizadores do mesmo. Além disso, pretendemos apontar uma visão teórica que vê, nesta mesma pulsão, e mesmo em suas manifestações patológicas, uma tentativa insistente de subjetivação e um protesto radical a favor da vida e da sobrevivência diante de um traumático aterrador e paralisante (De Oliveira et al, 2016; Zaltzman, 1994). Acreditamos que esta visão tem importantes desdobramentos na clínica psicanalítica, uma vez que aposta na possibilidade de trabalho e de um destino para o traumático desorganizador. 


\section{2 \\ A pulsão de morte em Freud}

A fim de estudarmos o conceito de pulsão de morte em Freud (1920/2006), acreditamos ser importante a contextualização de algumas questões clínicas e teóricas que fizeram com que o psicanalista pensasse ser necessária a postulação de uma nova pulsão. Dessa forma, percorreremos a teorização freudiana desde a conceitualização do primeiro dualismo pulsional, passando pela definição dos termos característicos de sua montagem até chegarmos ao momento em que a lógica da pulsão sexual pareceu insuficiente para explicar o que a clínica apresentava. Dentre essas manifestações clínicas, podemos destacar as neuroses traumáticas e o mecanismo de compulsão à repetição que apresentavam. Além disso, percorreremos outras obras freudianas (1923/2006, 1925/2006, 1930/2006), tendo em vista que estas apresentam reformulações importantes do conceito de pulsão de morte. Se, no início, tal pulsão foi pensada como uma tendência de retorno ao inorgânico, a partir das obras seguintes, podemos começar a pensá-la como movimentando a disjunção que possibilita, por sua vez, novas organizações. Além disso, veremos como o texto A Negativa (1925/2006) coloca a pulsão de morte no cerne da delimitação entre interno/externo, ou seja, da própria constituição psíquica, e justifica toda a teorização sobre o trabalho do negativo (Green, 1993/2010).

\section{1 \\ O conceito de pulsão e a primeira teoria pulsional}

Em 1915, em Instintos e as Suas Vicissitudes, Freud caracteriza a pulsão como tendo origem em fontes de estimulação dentro do organismo. É, portanto, impossível fugir desse estímulo, opção apenas possível contra estímulos provindos do meio externo. Visto que a fuga é a reação primeira do psiquismo, fuga impedida neste caso em função da fonte interna de estimulação da pulsão, a pulsionalidade obriga o aparato a encontrar outros e novos caminhos de possibilidade. O psiquismo lança mão então de mecanismos complexos a partir dos quais modifica o mundo externo e consegue propiciar, dessa forma, a satisfação dos estímulos internos (Freud, 1915/2006). 
Outra característica da pulsão apontada como fundamental é o constante impacto que esta exerce sobre o psiquismo, impacto esse que não cessa. Tendo isso em vista, a pulsão "designa algo que, nos seres vivos, propulsiona, incita, impele, põe em movimento, não deixa parar" (Winograd, 2013, p. 108). O aparato psíquico deve dar conta dessa constante estimulação, desse excesso pulsional, ligando-o e, assim, dominando-o. Definida como situada entre o anímico e o corporal, a pulsão é, portanto, uma exigência de trabalho psíquico em decorrência da ligação da mente com o corpo (Freud, 1915/2006). Podendo ser pensada como um estímulo para o psíquico, a pulsão aponta a possibilidade de articulação entre o mental e o somático. É por isso que Garcia-Roza (1987) afirma que devemos compreendê-la não como uma propriedade do corpo, mas como a maneira de articulação desse corpo com seus objetos.

Freud (1915/2006) define quatro termos que fazem parte da montagem do conceito de pulsão: sua pressão, sua finalidade, seu objeto e sua fonte. Por pressão, podemos entender o fator motor de que falamos acima, ou seja, a medida de trabalho exigida pela pulsão, e esta seria a própria essência do conceito. A finalidade da pulsão é sempre a satisfação, o que ocorre através da eliminação da estimulação em sua fonte. No entanto, Freud (1915/2006) atenta para a possibilidade de inúmeros caminhos levarem à finalidade, inclusive para finalidades intermediárias, que levam a satisfações parciais. A satisfação parcial está, inclusive, ligada à própria essência da pulsão, posto que esta é sempre constante. Essa satisfação "ocorre no campo do princípio do prazer, no campo dos objetos que se apresentam como pretendentes a objeto absoluto, mas que na verdade são da ordem da representação" (Garcia-Roza, 1987, p.91).

O objeto é aquilo através do qual a pulsão pode atingir a satisfação e se caracteriza como o aspecto mais variável de sua montagem, não estando originalmente determinado ou ligado à pulsão. No entanto, é somente através de um objeto que se pode chegar à finalidade pulsional, mesmo que esta seja parcial. Portanto, a pulsão pede um objeto, mesmo que este não seja específico ou absoluto. Por fonte "entendemos o processo somático que ocorre num órgão ou parte do corpo, e cujo estímulo é representado na vida mental por um instinto" (Freud, 1915/2006, p. 128). No entanto, de acordo com Freud (1915/2006), o conhecimento exato das fontes da pulsão não é necessário para a investigação psicológica, uma vez que esta só se faz presente no psiquismo 
através de seus representantes psíquicos. Isto significa que a pulsão está para além da distinção entre consciente e inconsciente.

No âmbito da primeira teoria das pulsões, Freud (1910/2006) havia caracterizado o dualismo pulsional opondo as pulsões de autoconservação, ou pulsões do ego, às pulsões sexuais. Mezan (2013) observa que ambas as pulsões podem inferir sobre os mesmos órgãos, uma vez que a boca, por exemplo, pode realizar tanto o ato de comer, relativo aqui à sobrevivência, quanto o ato de beijar, referido aqui ao sexual. Em A concepção psicanalítica da perturbação psicogênica da visão (Freud, 1910/2006), vemos que a cegueira histérica da paciente é explicada a partir do conflito entre as duas pulsões aqui definidas. As primeiras estão ligadas às funções indispensáveis à conservação da vida do indivíduo, tais como a fome. São as pulsões que impelem o indivíduo a manter-se vivo.

Já as pulsões sexuais atuam num campo muito mais amplo do que as atividades sexuais no sentido corrente do termo. Elas investem objetos externos e são fonte de prazer para o indivíduo. No dicionário Vocabulário de Psicanálise (Laplanche e Pontalis, 1997), encontramos que "a psicanálise mostra que a pulsão sexual no homem está estreitamente ligada a um jogo de representações ou fantasias que a especificam" (p. 403). Freud nomeou sua energia específica de "libido". Podemos pensar que a pulsão sexual constitui, como mostramos acima, um dos pólos do conflito psíquico das neuropsicoses de defesa, pólo contra o qual as defesas do ego, tais como o recalque, são erigidas. O recalcado retorna em função da própria insistência das pulsões sexuais.

No entanto, algumas questões se apresentam a essa primeira teoria pulsional, o que resultará, em 1920, na proposição da segunda teoria pulsional. Em Sobre o Narcisismo: Uma Introdução (1914b/2006), Freud busca responder à crítica junguiana de que sua teoria da libido não respondia aos problemas da psicose. Para Jung, a partir do conceito de narcisismo e da possibilidade do ego ser investido pela libido da pulsão sexual, parece haver uma única energia no aparato psíquico, o que indicaria uma concepção monista e confrontaria o conflito pulsional proposto por Freud. Mezan (2013) afirma que a hipótese de uma única energia eliminava "a especificidade do sexual, e com ela o ponto de partida da teoria freudiana do conflito neurótico" (p. 162). 
Na tentativa de defender seu dualismo pulsional, Freud (1914b) inicia, em resposta, a teorização mais profunda sobre o ego que já havia feito até então. Visto até essa teorização como uma espécie de perversão, a partir desse momento o narcisismo passa a definir um processo necessário e fundamental na constituição egóica. Localizado entre o auto-erotismo e a escolha objetal, o narcisismo se caracteriza como a própria condição de formação do ego, possível mediante o investimento vindo do exterior, investimento dos pais (Freud, 1914b/2006). Mesmo aqui, momento em que a relação com o objeto não estava tanto em questão, podemos notar sua importância na constituição subjetiva. Isso porque é o investimento dos pais neste momento primitivo que possibilita a constituição do narcisismo primário, a partir do qual as zonas erógenas parciais formam um conjunto organizado, ao qual chamamos de ego (Freud 1914b/2006; Mezan, 2013).

O ego aparece aqui como o grande reservatório da libido. Essa libido pode investir o próprio ego, caracterizando-se como libido narcísica, ou investir o mundo externo, caracterizando-se como libido objetal. O investimento da libido num objeto externo caracteriza a relação objetal, investimento possível a partir da formação do ego pelo narcisismo primário. Num momento posterior, a volta dessa libido para o ego caracteriza o narcisismo secundário. De acordo com Freud (1914b/2006), a vida é constituída pelo movimento dinâmico entre as duas formas de libido. A ideia é que quanto mais uma é empregada, mais a outra se enfraquece.

Porém, ao fazer tal diferenciação, mesmo afirmando que esta é "o corolário inevitável de uma hipótese original que estabelecia distinção entre os instintos sexuais e os instintos do ego" (Freud, 1914b/2006, p. 85), Freud parece introduzir uma questão semelhante à de Jung à sua teoria das pulsões: onde está a pulsão de autoconservação? A partir da distinção entre libido do ego e libido objetal, ambas energias da pulsão sexual, o lugar da pulsão do ego fica indefinido na teoria psicanalítica.

\section{2}

\section{A não dominância do princípio de prazer}

Seriam necessários mais alguns anos até que Freud pudesse responder à questão colocada pelo conceito de narcisismo. É em Além do Princípio do 
Prazer (1920/2006) que acontece uma importante reformulação do pensamento freudiano. A partir desse artigo, Freud (1920/2006) questiona-se sobre a dominância do princípio de prazer sobre os fenômenos psíquicos e volta-se mais profundamente ao que chamou de compulsão à repetição, o que o levou a postular a pulsão de morte e, consequentemente, instituir a segunda teoria pulsional. Mezan (2013) afirma que o conceito de pulsão de morte é "tão radicalmente novo e transtorna a rede da psicanálise de maneira tão profunda" (p. 253) que sua postulação deve ser tomada como ponto de partida para o início de uma nova teorização freudiana.

Até o momento, o princípio de prazer era pensado como um dos princípios que regiam o funcionamento do aparato psíquico. Podemos pensá-lo como um princípio econômico, uma vez que visa evitar o desprazer e garantir o prazer, aquele visto como aumento das tensões e este como diminuição. Portanto, o princípio de prazer orientaria o psiquismo na busca da satisfação da pulsão sexual, que acontece a partir da descarga imediata da excitação. Vemos, então, o funcionamento psíquico de um aparelho que funciona com o mínimo de tensão possível, e a máxima descarga energética. Quando a satisfação imediata não acontece, o primeiro artifício utilizado é a realização alucinatória do desejo. No entanto, essa produção alucinatória não trás a satisfação esperada. A frustração experienciada nesse momento produz o abandono dessa tentativa de satisfação e movimenta o aparato psíquico, que passa a mapear o mundo externo, a fim de encontrar formas de alterar a realidade que possibilitem a real satisfação. Assim, a partir da impossibilidade de satisfação ilimitada e do contato com as circunstâncias do mundo externo, o princípio de realidade é introduzido como novo princípio de funcionamento mental (Freud, 1911/2006).

Entretanto, a tendência do psiquismo continua seguindo na direção de se satisfazer e obter prazer. Freud (1911/2006) afirma que, ao invés de depor o princípio de prazer, a instauração do principio de realidade o protege. O que acontece é que, a partir da instauração do princípio de realidade, "a procura da satisfação já não se efetua pelos caminhos mais curtos, mas faz desvios e adia o seu resultado em função das condições impostas pelo mundo exterior" (Laplanche e Pontalis, 1997, p. 368). Ou seja, a busca da satisfação não é abandonada, o sujeito apenas passa a conseguir suportar o adiamento da 
satisfação imediata, que provocaria um prazer momentâneo, para que esta aconteça depois, de forma mais segura e garantida, abarcando o contexto e a realidade que o cercam. Nesse momento, o ego-prazer se transforma no egorealidade (Freud, 1911/2006).

No entanto, uma série de fenômenos faz Freud (1920/2006) flexibilizar a ideia de que o curso dos eventos mentais é invariavelmente regulado a partir do princípio de prazer. Até então, o funcionamento do aparelho psíquico era pensado como indo dominantemente na direção da redução da tensão, através da diminuição do desprazer e da produção de prazer. A partir de 1920, o princípio de prazer passa a ser pensado mais como uma tendência do funcionamento psíquico do que como um princípio ordenador. Freud (1920/2006) afirma que, se o princípio de prazer fosse realmente dominante no curso dos processos mentais, a maioria desses processos deveria resultar em prazer. No entanto, segundo o psicanalista, "a experiência contradiz completamente uma conclusão desse tipo" (Freud, 1920/2006, p. 19).

O primeiro dado a ser analisado e que parece ir contra a dominância de tal princípio é o fato de que este é pouco eficaz para a autopreservação do organismo. É, inclusive, perigoso para a segurança do indivíduo seguir somente a orientação do princípio de prazer e ignorar a realidade, motivo pelo qual este princípio é modificado para tornar-se o princípio de realidade. Como visto anteriormente, o princípio de realidade não abandona a tendência do psiquismo de buscar o prazer, mas, em nome da sobrevivência do indivíduo, por muitas vezes adia a satisfação e suporta o desprazer temporário como uma etapa antes que o prazer possa ser atingido. Com tal princípio, os fatores externos ao indivíduo e relacionados à realidade factual passam a ser levados em consideração na busca pela satisfação (Freud, 1911/2006).

De acordo com Laplanche e Pontalis (1997), “de início, as pulsões só procurariam descarregar-se, satisfazer-se pelos caminhos mais curtos. Fariam progressivamente a aprendizagem da realidade, a única que lhes permita atingir, através dos desvios e dos adiamentos necessários, a satisfação procurada" (p. 367). Ou seja, o princípio de realidade garante a satisfação na realidade, enquanto o princípio de prazer domina mais no âmbito das fantasias e, inclusive, das pulsões sexuais. A partir deste dado, já podemos observar como o princípio de prazer não pode ser a tendência absoluta de um psiquismo 
que sobrevive, mesmo que sua tendência norteadora seja a busca da satisfação e da diminuição das tensões.

Um segundo exemplo de funcionamento que não pode ser explicado através do princípio de prazer é a brincadeira do fort-da ilustrada em Além do Princípio do Prazer (1920/2006), que consiste no desaparecimento e retorno do objeto. A criança em questão repetia incansavelmente no brincar uma experiência aflitiva, que foi a partida da mãe. Tal evento não poderia ter sido vivido como prazeroso para a criança que, no entanto, insistia em repeti-lo. Parecia ser o caso de uma repetição não prazerosa sob nenhum ângulo. Abre-se a possibilidade de pensar em uma compulsão à repetição que "rememora do passado experiências que não incluem possibilidade alguma de prazer e que nunca, mesmo há longo tempo, trouxeram satisfação, mesmo para impulsos instituais que desde então foram reprimidos" (Freud, 1920/2006, p.31). Portanto, essa brincadeira também não se harmonizava, de forma alguma, com o princípio de prazer.

No entanto, o que parece estar em jogo no exemplo do fort-da é uma tentativa da criança de "tornar-se senhor" da experiência, passando da passividade com que vivera a cena inicial à atividade de dominá-la. Por mais desagradável que fosse repeti-la, nessas repetições a criança assumia um papel ativo no jogo. A dúvida de Freud neste momento é "se o impulso para elaborar na mente alguma experiência de dominação, de modo a tornar-se senhor dela, pode encontrar expressão como um evento primário e independentemente do princípio de prazer" (Freud, 1920/2006, p.27). O "primário” já aponta para tendências mais primitivas, para além desse princípio e, talvez, dele independentes. A questão é se a necessidade de elaboração pode ser anterior ao estabelecimento do princípio de prazer.

O terceiro fator de grande importância foi o estudo das neuroses de guerra ou neuroses traumáticas. Em Sobre os Sonhos (Freud, 1901/2006), em relação aos sonhos das crianças, Freud afirma que estes são "simples e indisfarçadas realizações de desejos" (p. 665). Isto significa que, na maioria das vezes, os sonhos das crianças são facilmente interpretáveis como realizações de desejos, muitas vezes relacionados a eventos ocorridos no dia anterior ao sonhar. Nessa concepção, os sonhos dos adultos seguem o mesmo caminho, sendo também realizações de desejos, com a diferença de que seus 
sonhos apresentam mais distorções do que os sonhos infantis, o que dificulta o trabalho de interpretação dos mesmos (Freud, 1900/2006).

Entretanto, os sonhos dos pacientes que apresentavam uma neurose traumática não se encaixavam na teoria dos sonhos postulada em $A$ Interpretação dos Sonhos (Freud, 1900/2006). Ou seja, tais sonhos não pareciam se realizações de desejos inconscientes, não se harmonizando, portanto, com o princípio de prazer. Nesses casos, os sonhos não tratavam de satisfações substitutivas trazendo o retorno do recalcado, mas de repetições de experiências aflitivas e angustiantes, experiências que os sujeitos supostamente deveriam se esforçar para esquecer, e não reviver de forma compulsiva. Repetidamente, esses sonhos traziam o paciente de volta à situação traumática, mantendo assim a tensão constantemente alta e provocando o despertar dos sonhadores em um susto. Podemos, portanto, observar uma relação entre as neuroses traumáticas, a brincadeira da criança do fort-da e a compulsão à repetição de situações que não poderiam causar prazer ao indivíduo. Eram todos fenômenos que não podiam ser explicados a partir da lógica da pulsão sexual (Freud, 1920/2006). Que lógica os explicaria?

\section{3 \\ As neuroses traumáticas: um novo paradigma de trauma}

Em 1920, Freud voltou-se para a problemática com a qual se confrontava em relação às neuroses traumáticas, atentando para o fato de que alguns pacientes também repetiam, em seu consultório, experiências passadas traumáticas que não lhes causavam nenhum prazer. Chamava a atenção do psicanalista os casos em que parecia ocorrer uma "perpétua recorrência da mesma coisa" (Freud, 1920/2006, p. 33). Eram casos em que situações se repetiam na vida dos sujeitos, que experienciavam de forma passiva as fatalidades que aconteciam, não parecendo ocupar um papel ativo em tais situações repetitivas.

Em Além do Princípio de Prazer (1920/2006), Freud tenta responder a todas essas questões aparentemente inexplicáveis pela lógica da pulsão sexual. Para isso, se debruça sobre a questão desse traumático que retornava compulsivamente nos sonhos dos neuróticos de guerra. Numa tentativa de 
pensar em como se dava esse trauma, Freud (1920/2006) nos fala sobre a camada protetora do psiquismo. Tal camada se caracteriza como a parte externa do aparelho psíquico, possibilitando a proteção contra estímulos muito intensos. A proteção contra os estímulos é pensada como uma função tão importante quanto a recepção dos mesmos. No sentido do exterior, o sistema se encontra protegido contra os estímulos que sobre ele incidem. No entanto, contra os estímulos provindos do interior tal escudo protetor não é possível.

Como consequência, tais estímulos provindos de dentro, ou seja, a pulsionalidade, têm uma forte incidência sobre $\mathrm{o}$ aparato psíquico, ocasionando, em primeiro lugar, que os sentimentos de prazer e desprazer sejam mais predominantes para o psiquismo do que os estímulos provindos de fora. Em segundo lugar, o aparato psíquico se utiliza do mecanismo da projeção para se defender dessas excitações internas, quando geradoras de desprazer: "há uma tendência a tratá-las como se atuassem, não de dentro, mas de fora, de maneira que seja possível colocar o escudo contra os estímulos em operação, como meio de defesa contra elas" (Freud, 1920/2006, p. 40).

Sendo a recepção dos estímulos uma das principais funções do psiquismo, em Além do Princípio de Prazer (1920/2006), Freud define como traumáticas as excitações provindas do exterior ao aparato que rompem o escudo protetor. Esse traumático é, então, a inundação do psiquismo por tais excitações, o que põe o princípio de prazer momentaneamente fora de ação. Isso acontece porque, nesta situação, não é mais possível impedir a entrada do excesso e nem proteger o psiquismo do inundamento já ocorrido. Sem mais poder se defender da invasão, a energia do aparelho psíquico é voltada para mobilizar as medidas defensivas necessárias para dominar os estímulos e vinculá-los, a fim de que seja possível deles se desvencilhar.

Freud (1920/2006) afirma que um dos motivos pelos quais o aparelho psíquico não teria podido receber tal intensidade seria sua falta de preparação para isso, o que seria consequência do 'elemento de susto'. Sem a angústia que dá o sinal para os sistemas que recebem o estímulo, acontece o rompimento do escudo e a consequente invasão do aparelho, sem que este consiga realizar a vinculação da energia excessiva e invasora. A consequência de tal rompimento é que o aparelho psíquico entra, a partir daí, numa tentativa de elaborar o excesso, num modo de funcionamento traumático, na medida em que, em 
detrimento de outras atividades psíquicas, toda a energia do sistema é investida de modo a dominar a excitação invasora, desencadeando uma neurose traumática.

O traumático da neurose traumática pode ser pensado a partir do modelo econômico. Segundo Bokanowski (2005), é o traumatismo: "relacionado às aporias econômicas do aparelho psíquico, o que nos conduz a uma mudança de paradigma. Contrariamente a um excesso de sedução externa ou interna que caracterizava o período precedente, o traumatismo será doravante ligado a um defeito de pára-excitação" (p. 28). Ou seja, nessas patologias, diferentemente do caso das neuropsicoses de defesa, o traumático não se caracteriza pelo sexual e as fantasias que a partir dele surgem, embora a importância de tal fator não deva ser descartada. No entanto, na etiologia do traumático das neuroses de guerra, ou neuroses traumáticas, estão o terror e o medo da morte, ameaças ao ego provindas de fora.

Pelo fato do psiquismo estar desprotegido contra as excitações vindas do interior do corpo, estas podem também provocar perturbações econômicas tão traumáticas quanto às excitações vindas do exterior. O pulsional é tão externo ao aparelho psíquico quanto a realidade exterior, podendo, dessa forma, também ser considerado como traumático. Nesses casos, “o pulsional é traumático porque a força pulsional não é absorvida por inteiro no universo significante, porque irrompe como um "corpo estranho" no aparelho egóico, não submetido ao princípio de prazer" (Lejarraga, 1996, p.31). No entanto, esse traumático resultante do excesso pulsional pode ter dois efeitos: estruturante ou desestruturante para o aparato psíquico. No primeiro caso, o ego sucede no trabalho de produção de sentido e de novas representações para o pulsional ainda não significado, e, assim, o integra a uma rede de sentidos. Tendo em vista que o desconhecido ameaça a integridade egóica, o ego procurará acolhêlo dentro de sua rede de representações (De Oliveira \& Winograd, 2016). Portanto, vemos como a pulsionalidade força o trabalho psíquico e um movimento de subjetivação.

No entanto, nos casos em que o ego não consegue realizar esse trabalho de ligação e representação do excesso pulsional, seja pela intensidade do estímulo, seja por algum fator relacionado à capacidade de metabolização do próprio ego, o efeito do traumático é desestruturante, provocando o movimento 
da compulsão à repetição que busca realizar a ligação da excitação. Dessa forma, as vivências nas neuroses traumáticas se caracterizam pelo sentimento de terror e pela angústia extrema, ambos provocados pela experiência de ameaça de morte psíquica. O terror é a sensação de pavor diante de um perigo que não se espera e para o qual não houve preparo. Esse terror é o que provoca a invasão do ego e seu consequente desamparo diante dessa experiência: "o 'terror' traduziria o estado do aparato ao ser subitamente invadido, ficando o ego 'petrificado de terror', nada tendo podido fazer para ligar a excitação" (Borges, 2012, p. 33). Isso significa que o psiquismo é invadido por esse excesso, o que paralisa os mecanismos psíquicos necessários para confrontá-lo, como as funções mnêmicas egóicas.

Essa invasão provoca uma momentânea suspensão da dominância do princípio de prazer. Dentro desse contexto traumático, o parâmetro prazer/desprazer não é o mais primordial, sendo urgente a transformação da energia livre que inunda o psiquismo em energia ligada. $\mathrm{O}$ ego está diretamente relacionado à noção de ligação, por ser o sistema responsável por essa função, sendo investido constantemente e inibindo a descarga imediata de energia. Aqui, podemos associar o princípio de inércia ao processo primário, no qual a energia tende a ser descarregada imediatamente, enquanto o princípio de constância está associado ao processo secundário, no qual a energia é ligada por essa ação inibitória exercida pelo eu (Freud, 1920/2006).

Portanto, a ligação é necessária para o funcionamento do princípio de prazer, uma vez que possibilita a circulação dos desejos inconscientes nas cadeias de representações. Na realidade, esta seria a condição para o funcionamento do aparato psíquico, que fica prejudicado em uma situação de invasão traumática. É através da ligação que o excesso pulsional traumático pode ser assimilado e depois descarregado, uma vez que esta "levanta a questão da transposição de dois registros diferentes, de um registro energético, quantitativo, de pura força pulsional, para um registro representacional, para o plano da circulação do desejo nas cadeias significantes” (Lejarraga, 1996, p. 34). A ligação está referida então à inscrição da energia em um registro representacional, inscrição sem a qual a força pulsional se configura como traumática. Assim, é possível pensar que a tendência do princípio de prazer só pode ser estabelecida quando as energias estiverem ligadas psiquicamente. $\mathrm{O}$ 
para além desse princípio corresponde a um registro energético não representado. Tal questionamento foi possível somente em Além do Princípio de Prazer (Freud, 1920/2006), através do estudo das neuroses traumáticas, uma vez que a histeria e a neurose obsessiva, as neuroses clássicas, apresentavam sintomas inseridos dentro das cadeias de representações e cuja lógica era explicada pela pulsão sexual.

\section{4}

\section{A compulsão à repetição e a segunda teoria pulsional}

As neuroses traumáticas introduzem uma nova questão na teoria psicanalítica, uma vez que seu modelo de trauma e seus respectivos efeitos apresentam aspectos diferentes dos das neuropsicoses de defesa, as neuroses cujo estudo estimulou o nascimento da psicanálise. Se em relação às neuropsicoses de defesa a sintomatologia estava referida à pulsão sexual e às defesas utilizadas contra os desejos inconscientes (Freud, 1896b/2006, 1896c/2006), os casos de neuroses traumáticas apontavam para uma outra lógica de funcionamento do aparato psíquico, uma lógica ainda mais primitiva do que a das neuroses clássicas.

A neurose traumática é, de acordo com Borges (2012) “uma ferida emocional profunda, causada por uma agressão psíquica, intencional ou não, que transtorna globalmente o psiquismo afetado, por efração energética ampliada, num organismo não preparado" (p. 23). O excesso invasor do aparelho psíquico nas neuroses traumáticas ocasiona defesas egóicas bem distintas das utilizadas pelas neuroses clássicas ao se defenderem da pulsão sexual. A ameaça de morte psíquica vivenciada pelo ego, a vivência inominável que está para além da possibilidade de representação, provoca defesas egóicas que buscam evitar o retorno do terror vivenciado e são regidas pela compulsão à repetição.

Da mesma forma, os sonhos dos pacientes que apresentavam neuroses traumáticas não seriam realizações de desejos inconscientes. Tais sonhos reviveriam as situações traumáticas no intuito de dominá-las retrospectivamente, promovendo por isso a angústia que faltou no momento do trauma. O domínio e a ligação do excesso pulsional que essa repetição dos 
sonhos procuraria seria tarefa necessária para que o princípio de prazer pudesse ser instaurado. Tarefa, portanto, anterior a este princípio. Os sonhos das neuroses traumáticas possibilitaram, portanto, o conhecimento de uma função do aparelho mental independente do princípio de prazer. Mesmo que não o contrariasse, essa função parecia ser ainda mais primitiva do que a busca de prazer orientada por aquele princípio (Freud, 1920/2006).

A partir das neuroses traumáticas, podemos pensar num fenômeno de compulsão à repetição cujo funcionamento não é regido pelo princípio do prazer. Os sonhos das neuroses traumáticas se caracterizam como tentativas compulsivas de realizar a ligação das impressões traumáticas A função de afastar o que pudesse interromper o sono, através da realização dos desejos dos estímulos perturbadores, não é a função original dos sonhos. Na realidade, os sonhos só podem realizar essa função se todo o aparelho psíquico estiver sob a dominância do princípio de prazer. A compulsão à repetição observada nos sonhos das neuroses traumáticas apresenta, para Freud (1920/2006), "algo que parece mais primitivo, mais elementar e mais instintual do que o princípio de prazer que ela domina" (p. 34).

Roudinesco e Plon (1998) afirmam que a compulsão à repetição é um conceito que busca dar conta do processo inconsciente que faz com que o sujeito reproduza sequências que lhe provocaram sofrimento desde a origem e que permaneceram geradoras de sofrimento em sua repetição. Ou seja, a compulsão à repetição observada em alguns casos clínicos e nos sonhos das neuroses traumáticas rememora situações que não podem ser prazerosas para nenhuma instância do psiquismo. Tendo isso em vista, Freud (1920/2006) supõe que tal mecanismo, cuja atuação é independente do princípio de prazer, aponta, na realidade, para algo além dele.

Além disso, essa compulsão mantém um alto nível pulsional, o que faz parecer que há uma força “demoníaca” (Freud, 1920/2006, p. 46) em ação. No entanto, já vimos que, nesses casos, o sujeito repete na tentativa de elaborar o excesso traumático e, assim, conseguir sair dessa posição. Portanto, tal repetição se apresenta como tentativa radical de defesa do psiquismo, tentativa de realizar a ligação necessária para dominar o excesso que o invadiu e metabolizar psiquicamente o que não foi elaborado. É por isso que Borges 
(2012) afirma que se trata "em última instância, de uma defesa contra a morte psíquica” (p. 22).

A repetição à qual Freud se refere em Além do Princípio de Prazer (Freud, 1920/2006) é diferente da repetição de Recordar, Repetir e Elaborar (Freud, 1914a/2006). Enquanto a última está no registro da representação, se caracterizando como a repetição de protótipos infantis, substitutiva então de um desejo inconsciente, a primeira, apesar de poder recordar também experiências do passado, repete algo que não chegou a ser processado simbolicamente, não havendo, então, um desejo inconsciente procurando a satisfação. A compulsão à repetição não substitui a recordação, posto que não há o que recordar. Ao contrário, trata-se de construir como representação o que ficou no registro da experiência corporal. Garcia-Roza (1987) estabelece uma diferença entre estes dois tipos de repetição, que são: 'a repetição do 'mesmo' e a repetição diferencial; enquanto a primeira se aproxima da reprodução (na medida em que é estereotipada), a segunda é produtora de novidade e, portanto, fonte de transformações". (p.24)

A repetição diferencial possibilita a produção de novidades, uma vez que o desejo inconsciente que repete é passível de interpretação e elaboração. Quanto à repetição do mesmo, ou a compulsão à repetição, esta se apresenta como uma tentativa de simbolização, sem que exista ainda a representação e o desejo do indivíduo. A última repetição é, portanto, de um mesmo, idêntico, mas ainda assim caracterizada pelo alto grau pulsional, uma vez que a repetição é característica da pulsão (Garcia-Roza, 1987). A repetição do mesmo se caracteriza como uma tentativa de defesa, antes mesmo que o princípio de prazer possa se instaurar como tendência.

Em Além do Princípio de Prazer (Freud, 1920/2006), vemos a ideia de que há algo para além, ou melhor, para aquém deste princípio como uma novidade. No entanto, Caropreso e Simanke (2006) argumentam que este tipo de funcionamento só é uma novidade se referido ao aparelho psíquico de $A$ Interpretação dos Sonhos (Freud, 1900/2006), uma vez que o Projeto para uma Psicologia Científica (Freud, 1895/2006) traz, desde as origens do pensamento freudiano, uma forma de funcionamento psíquico que opera a partir da compulsão à repetição. Deste modo, os autores afirmam que as ideias de 1920 resgatam esta primeira hipótese esquecida. Em 1895, o processo 
primário indica o funcionamento a partir do qual a energia segue o caminho mais bem facilitado. Tanto a vivência de satisfação quanto a vivência de dor operariam a partir desse processo, sendo que a intensidade da vivência de dor é maior. O processo secundário seria resultado do direcionamento do primeiro processo a partir do ego, quando constituído.

Devido a intensidade da vivência de dor, o ego teria mais dificuldade de inibir os processos relacionados à essa vivência do que os relacionados à vivência de satisfação, o que significa que "a inibição da ocupação intensa da representação do objeto hostil seria um processo gradual, que pressuporia o estabelecimento da excitação em estado ligado" (Caropreso \& Simanke, 2006. p. 211). O domínio das excitações se faz aqui através da repetição. Freud (1895/2006) nos diz que as primeiras repetições das vivências de dor ainda despertariam afeto e desprazer, até que com o tempo essa característica diminuiria. O que nesse momento o autor chama de "representações indomadas" é o que mais tarde veremos como o excesso não representado que desencadeia a neurose traumática (Freud, 1895/2006, 1920/2006). São quantidades que rompem o escudo protetor e as quais o ego não consegue ainda “domar”. Para domá-las, o ego precisa realizar a ligação e integrá-las, na linguagem do Projeto (Freud, 1895/2006), aos circuitos neuronais. Portanto, é aqui que se inscreve o movimento de compulsão à repetição, nessa tentativa de integrar tais representações.

O que vemos no Projeto (Freud, 1895/2006) é que, no início, o ego não tem como inibir as representações de vivência de dor, não podendo impedir o desprazer advindo disso. Nesse momento, o reencontro com o que dói se dá porque ainda não há o véu da fantasia. Dessa forma, a compulsão à repetição é chamada na tentativa de processamento e de saúde. Sem ela, não há constituição subjetiva. Podemos, portanto, ver desde o começo da obra freudiana indícios de um funcionamento repetitivo que é necessário até que a excitação seja ligada. No entanto, Caropreso e Simanke (2006) apontam para o fato de que, em A Interpretação dos Sonhos (Freud, 1900/2006), Freud não fala mais das representações indomadas, como se as representações relativas às vivências de dor fossem excluídas do psiquismo. De acordo com os autores, “aquilo que seria, no Projeto, uma aquisição secundária no modo de tratar as consequências da vivência de dor, passa a ser, no capítulo 7, algo que faz parte 
do funcionamento psíquico desde sua origem" (Caropreso \& Simanke, 2006, p. 215). É como se o psiquismo orientado pelo princípio de prazer pudesse, desde o início, evitar a liberação de desprazer relativa às representações da vivência de dor, restando somente a experiência de satisfação na origem da constituição subjetiva.

Caropreso e Simanke (2006) afirmam, portanto, que quando Freud (1920/2006) fala do trauma das neuroses traumáticas e da repetição de situações não prazerosas desde sua origem, ele retoma, em boa parte, o que dizia sobre a vivência de dor em 1895, "esclarecendo qual pode ser a função de um processo que anteceda o princípio de prazer" (Caropreso \& Simanke, 2006, 220). Desta forma, a compulsão à repetição não atenderia sob nenhum aspecto às exigências do princípio de prazer, se apresentando como uma tentativa de ligação necessária para que aquele princípio fosse estabelecido. Em 1920, a ideia de algo que motive o psiquismo para além deste princípio, leva à postulação de um pulsional para além também da pulsão sexual e da pulsão de autoconservação. Freud (1920/2006) atribui o caráter repetitivo dos fenômenos da compulsão à repetição a uma tendência própria das pulsões. Dessa forma, a pulsão de morte é originalmente caracterizada como "uma expressão da natureza conservadora da substância viva" (Freud, 1920/2006, p.47), expressão de uma tendência do organismo a retornar ao estado inanimado, o estado anterior de coisas. É a tradução de uma impossibilidade de escapar de um movimento de retorno.

Lejarraga (1996) afirma que, uma vez que a pulsão de morte aspira ao retorno ao inorgânico e, portanto, ao zero de tensão, esta se caracteriza como a “pulsão por excelência" (1996). O psiquismo também apresenta essa tendência de zerar as tensões, ou ao menos mantê-las tão baixas e constantes quanto fosse possível. Em Além do Princípio de Prazer (Freud, 1920/2006), Freud afirma que tal tendência encontra forma no princípio de prazer, e que este princípio parece servir, por isso, à pulsão de morte que, no limite, visa o esvaziamento completo das tensões do psiquismo. $\mathrm{O}$ mecanismo da compulsão à repetição efetua a descarga do excesso pulsional, mesmo que somente momentaneamente. Deste modo, essa repetição parece trabalhar também na tentativa de reduzir a tensão do aparelho. 
Com a postulação da pulsão de morte, a teoria das pulsões sofre uma mudança radical. O primeiro dualismo pulsional, caracterizado pela oposição entre as pulsões sexuais e as pulsões de autoconservação, é substituído pelo segundo dualismo pulsional, que opõe as pulsões de vida, Eros, que abarca ambas as pulsões da primeira teoria pulsional, às pulsões de morte. Em $O E g O$ e o Id (Freud, 1923/2006), Freud defende que, em maior ou menor medida, as pulsões de vida e de morte estão sempre articuladas nos processos psíquicos. Falar em uma fusão das pulsões possibilita pensar em uma desfusão, o que provocaria o surgimento pronunciado da pulsão de morte em algumas patologias, entre elas as neuroses obsessivas e os casos limite. Ambas as pulsões expressam diferentes modos de presentificação no aparato psíquico: a pulsão de vida é conjuntiva e a pulsão de morte disjuntiva.

As pulsões de vida seriam mais fáceis de observar, uma vez que são barulhentas e expansivas. Quanto às pulsões de morte, estas se caracterizam por sua face silenciosa, não podendo ser distinguidas isoladamente. A pulsão de morte só poderia ser analisada em suas manifestações de compulsão à repetição ou agressividade, quando fusionada a Eros e direcionada a objetos (Freud, 1923/2006). De acordo com Lejarraga (1996) esse dualismo pulsional não expressa uma oposição simétrica, “já que as pulsões de morte não se representam no inconsciente - são mudas - enquanto as pulsões sexuais se inscrevem no psiquismo através de seus representantes" (p. 37).

Enquanto Eros se esforça por criar laços e combinar a substância viva em unidades cada vez maiores, a pulsão de morte, Tanatos, busca dissolver essas unidades, conduzindo-as de volta ao seu estado inorgânico, o que provoca a desunião, mas também a diferença. Garcia- Roza (2004) afirma que a pulsão de vida é conservadora e que, sem a ação da pulsão de morte, não pode haver diferenciação, uma vez que o projeto de Eros é a eliminação do desejo e a chegada a uma indiferenciação maior na humanidade. Assim, a dialética Eros-Tanatos consiste num constante movimento de criação de novas formas e de destruição dessas formas estabelecidas, o que possibilita um recomeço e uma nova criação de formas no aparato psíquico. Portanto, a vida se constitui em "um conflito e uma conciliação entre essas duas tendências" (Freud, 1923/2006, p. 53). Deste modo, o novo dualismo pulsional pode ser pensado como um dualismo entre um princípio conjuntivo e organizador de 
Eros e um princípio disjuntivo e de destruição da pulsão de morte. De acordo com Laplanche e Pontalis (1997),

A pulsão sexual, que na primeira teoria das pulsões Freud contrapõe às pulsões de autoconservação, é assimilada no último dualismo às pulsões de vida ou a Eros. Enquanto no primeiro dualismo ela era a força submetida exclusivamente ao princípio de prazer, dificilmente "educável", funcionando segundo as leis do processo primário e ameaçando constantemente do interior o equilíbrio do aparelho psíquico, torna-se, sob o nome de pulsão de vida, uma força que tende à "ligação", à constituição e manutenção das unidades vitais; e, em contrapartida, é a sua antagonista, a pulsão de morte, que funciona segundo o princípio de descarga total (p. 404).

Apesar do conceito de pulsão de morte ter sido postulado em 1920, é somente anos depois, em O Mal-Estar na Civilização (Freud, 1930/2006) que Freud caracteriza a autonomia da pulsão de morte, uma vez que sustentar a destrutividade como disposição pulsional independente do sexual parecia uma ideia de difícil aceitação (Garcia-Roza, 1990). Oliveira et al. (2016) observam que a dificuldade aqui parecia ser a de "relativizar a disruptividade libidinal, tornada moeda corrente na teoria psicanalítica" (p. 2).

Inclusive, Cromberg (2014) afirma que o conceito de pulsão de morte de Freud (1920) teria tido inspiração na teoria de Sabina Spielrein, mas que o autor recalcou o conceito spielreiniano, fazendo somente pequena menção à Spielrein em uma nota de rodapé de Além do Princípio de Prazer (Freud, 1920/2006). Em seu texto A Destruição como Origem do Devir (1912/2014), escrito anos antes da postulação da pulsão de morte por Freud, Spielrein parece apontar para a destrutividade presente na sexualidade e argumenta que o 'componente da morte' é indispensável para o processo de criação, sendo a transformação o produto da destruição. Para Cromberg (2014), o texto de Spielrein (1912/2014) apresentou uma novidade radical demais para a época, o que impossibilitou que sua obra fosse assimilada na teoria psicanalítica e provocou o esquecimento da autora, descrita por Cromberg (2014) como pioneira.

Portanto, na teorização freudiana, é somente em 1930, em o Mal Estar na Civilização, que a pulsão de morte, entendida aí como pulsão de destruição e originária no ser humano, tem sua autonomia reconhecida, o que significa que a energia desta pulsão não é a libido da pulsão sexual. A partir daí, destrutividade e sexualidade passam a ser consideradas duas forças autônomas 
uma em relação à outra. A destrutividade é apontada nesse momento como o principal representante da pulsão de morte, dividindo o mundo com Eros, e é pensada como o maior empecilho à civilização. A evolução da civilização representaria a mesma luta entre Eros e pulsão de morte que ocorre nos indivíduos (Freud, 1930/2006).

\section{5 \\ O lugar do irrepresentável na psicanálise}

Pela sua tendência de rompimento de laços, podemos pensar a pulsão de morte como energia livre e desligada e perceber, a partir daí, um desdobramento da segunda teoria pulsional: o dualismo entre o representado, o inscrito e a energia dispersa, energia pulsional que não se representa (GarciaRoza, 1996). O traumático de Além do Princípio de Prazer (Freud, 1920/2006) pode ser caracterizado, então, como a irrupção da própria pulsão de morte no psiquismo, o que escapa ao domínio da representação.

De acordo com Garcia-Roza (1996), “a pulsão de morte é invisível e silenciosa, poderíamos dizer invisível e indizível. Ora, o que está fora ou para além da visibilidade e da dizibilidade, está para além da representação (visível) e da palavra (dizível)" (p. 159). O autor afirma ainda que distinguir a pulsão propriamente dita de sua forma de aparecimento no aparato psíquico implica em admitir duas regiões no campo psicanalítico: uma do próprio aparato, regida pelo princípio de prazer e outra para além dessa regência, que diz respeito à pulsão propriamente dita.

Enquanto a pulsão sexual está sob o regime do princípio do prazer, referida ao aparato anímico e dentro do espaço da representação, a pulsão de morte é aquilo que está para além do princípio de prazer, para além do próprio aparato psíquico. Dessa forma, podemos dizer, mais uma vez, que a pulsão de morte é a pulsão por excelência. Assim, a pulsão de morte designa o que está para além do sexual, para além das cadeias de representações. Garcia-Roza (1996) defende ainda que as pulsões, em si mesmas, não possuem ordem alguma. Enquanto pura energia, elas não apresentam um sentido pré-definido, seja ele sexual ou de agressividade. 
Por não apresentarem um objeto natural e próprio, a satisfação das pulsões só pode ser alcançada através da mediação pela representação. É somente através da fantasia que a satisfação pode ser atingida e que a pulsão sexual se caracteriza como tal, exatamente por suas máscaras. Esta se constitui, então, através da ligação com um objeto que possa promover prazer ou desprazer. Sem o investimento objetal, há apenas a pulsão de morte. Nas palavras de Garcia-Roza (1996), "pulsão de vida e pulsão de morte seriam modos de presentificação da pulsão no psiquismo e não qualidades das pulsões elas mesmas" (p. 162).

O que o conceito de pulsão de morte, e a própria segunda teoria pulsional, introduzem na teoria freudiana é a possibilidade de se pensar em um funcionamento fora da dominância do princípio de prazer (Garcia-Roza, 1996). A dominância deste princípio se refere apenas ao funcionamento do aparelho psíquico e da realidade psíquica. Com a introdução da pulsão de morte, foi possível pensar numa outra região, para além do aparato mental e de sua ordem, a região do "caos pulsional”. Garcia-Roza (1996) afirma que, no limite, o verdadeiramente pulsional é o que permanece fora da ordem, sem sentido: "a pulsão ocupa um outro lugar, situado além da ordem e da lei, além do inconsciente e da rede de significantes, além do princípio de prazer e do princípio de realidade, além da linguagem: é o lugar do acaso" (p. 127).

No entanto, só podemos falar em pulsão após a diferenciação entre as duas pulsões, o que reafirma a constante articulação entre os dois modos de ser da pulsão. Entre o acaso das pulsões e a ordem do aparato anímico, há sempre uma coexistência, posto que nenhuma das pulsões se apresenta em estado puro. Garcia-Roza (1996) apresenta uma interpretação da pulsão de morte diferente da postulada em Além do Princípio de Prazer (Freud, 1920/2006), trabalho em que Freud defende que esta é uma pulsão conservadora. Na visão de GarciaRoza, enquanto pura potência, a pulsão de morte é criadora, renovadora e produtora de diferenças, indo contra a direção da unificação e indiferenciação que busca a pulsão de vida. É através de sua potência destrutiva que a pulsão de morte desfaz os laços e as formas de Eros, aqui pensada como a pulsão conservadora (Garcia-Roza, 1996, 2004).

Em concordância com essa ideia, De Oliveira \& Winograd (no prelo) afirmam que, ao confrontar o ego com uma energia desligada e, portanto, ainda 
não representada, a pulsão de morte força o aparato no sentido de produzir algum sentido, criando, assim, novas formas: “o trabalho da pulsão de morte força o Eu a sair do regime do mesmo, na medida em que o confronta com a ausência de representação, obrigando-o a trabalhar na direção da cobertura do irrepresentável" (De Oliveira e Winograd, no prelo, p. 5). Deste modo, é a energia livre da pulsão que morte que forçará o aparato psíquico a construir novas ligações e representações que possibilitarão a diferença. Esse excesso pulsional é, como vimos acima, produtor de subjetividade e estruturante para o psiquismo. No entanto, dentro da problemática das neuroses traumáticas, o traumático desestruturante se dá pela impossibilidade de representação e de elaboração dessa força pulsional. Nesses casos, o psiquismo teria sido atingido por um excesso pulsional superior a suas capacidades de metabolização.

Podemos pensar que, com a segunda teoria pulsional, o que Freud (1920/2006) introduz em sua teoria é a possibilidade de se pensar o irrepresentável no psiquismo. Esse irrepresentável poderia funcionar como produtor de diferenças ou como desestruturante do aparato psíquico, tendo em vista que "é a relação entre a intensidade que atinge o aparato e suas capacidades de ligação e de organização das excitações que confere à quantidade valor de efração ou valor de empuxo à produção" (De Oliveira e Winograd, no prelo, p. 13). Portanto, de acordo com Knobloch (1998), a partir de 1920 e em consequência dessa nova concepção econômica do traumático e da postulação da pulsão de morte, a problemática da psicanálise não se volta mais apenas para a sexualidade, mas para

uma nova pulsão cujo princípio é o desligamento, desunião da vida do sujeito com o objeto, da sexualidade com a palavra, do fato penoso com a função da fantasia, etc. Esta é a virada dessa época. Há algo mais que a sexualidade e o prazer, algo que, no psíquico, funciona contra o próprio sujeito, algo mais do que o sujeito (p. 108)

Além da segunda teoria pulsional, a segunda tópica freudiana, que estabelece a divisão no psiquismo das instâncias do ego, id e superego, enquanto a primeira dividia o aparelho psíquico em pré-consciente/consciente e inconsciente (Freud, 1900/2006, 1923/2006), abrem a possibilidade de se pensar no lugar do não representado e, em conseqüência, em patologias que antes não eram estudadas pela psicanálise. Knobloch (1998) nos diz que, na segunda tópica, Freud integra "a pulsão ao aparelho, enquanto na primeira 
tópica ela está fora dele" (p. 95). A partir dessa integração, o irrepresentável é abarcado pela teoria. Enquanto na primeira tópica havia somente a presença da sexualidade, na segunda a pulsão de morte é incluída ao psiquismo.

Quando tratava apenas das neuroses clássicas, Freud (1914a/2006) pensava que quadros clínicos que não pudessem sustentar o enquadre analítico e não fossem passíveis de ser interpretados não poderiam ser ajudados pela psicanálise, o que tinha como resultado que apenas as neuroses de transferência poderiam estar dentro do alcance psicanalítico. No entanto, a nova concepção do traumático, a segunda teoria pulsional e a segunda tópica freudiana possibilitaram que se pudesse pensar num novo tipo de funcionamento psíquico, na medida em que, a partir deles, o não representado e aquilo que não foi inscrito encontram um lugar na teoria psicanalítica, que passa a trabalhar para possibilitar que se torne palavra o que não foi falado, escutando o traumático que não foi significado. Os casos limite, antes considerados como não analisáveis e representando um limite para a teoria e a técnica, podem ser incluídos na área de trabalho da psicanálise.

\section{6}

\section{A negativa: a pulsão de morte como constitutiva do psiquismo}

Desde o momento de sua postulação, o conceito de pulsão de morte foi objeto de questionamentos e, ao longo da teoria freudiana, sofreu diversas mudanças. Como já vimos, em 1920 e em 1923 ele era pensado, respectivamente, como uma tendência de retorno ao inorgânico e como um princípio disjuntivo e de destruição. No entanto, em A Negativa (Freud, 1925/2006) podemos ver uma face diferente dessa pulsão de morte. É possível pensar que esse artigo atribuiu um novo lugar ao conceito na teoria psicanalítica, uma vez que o colocou como importante na constituição psíquica.

Em A Negativa (1925/2006), Freud apresenta uma discussão sobre a negação. Se antes estava voltado para o estudo dos processos inconscientes, agora se debruça sobre um mecanismo da linguagem e, portanto, consciente. Cita situações em que pacientes seus negaram uma ideia que ele próprio não havia sugerido, o que levantava a hipótese de ter sido uma ideia que acabara de ocorrer aos pacientes mesmos. É o exemplo do paciente que, ao ser perguntado 
sobre quem era a mulher de um sonho que relatara, respondeu: "não é a minha mãe" (Freud, 1925/2006, p. 265). De acordo com Freud (1925/2006), dessa forma os conteúdos recalcados dos pacientes vinham à consciência, mas em forma de negação. Através dessa negativa, o inconsciente podia ser revelado. Esse juízo negativo se apresentava como uma substituição intelectual do processo do recalque.

Freud (1925/2006) nos diz que "a negativa constitui um modo de tomar conhecimento do que está reprimido; com efeito, já é uma suspensão da repressão, embora não, naturalmente, uma aceitação do que está reprimido" (p. 266). O recalcado é, dessa forma, revelado somente intelectualmente, mas o essencial do processo do recalque permanece, uma vez que os afetos permanecem recalcados. Nesses casos, o intelectual parece estar então separado da afetividade, o que conduz Freud (1925/2006) à uma discussão sobre os processos de pensamento. Duas espécies de juízos são diferenciadas: o juízo de atribuição e o juízo de existência.

O juízo de atribuição está ligado ao ego-prazer inicial, que apresenta um funcionamento regido pelo princípio de prazer. Dentro dessa lógica, introjeta para dentro de si tudo o que é considerado bom e ejeta para fora de si tudo o que é considerado ruim. Encontramos aqui uma afirmativa misteriosa de Freud (1925/2006): “o mau, aquilo que é estranho ao ego e que se encontra fora, é inicialmente idêntico a ele" (p. 23). A partir disso, podemos pensar que não há uma diferenciação entre dentro e fora desde o começo da vida psíquica. Esse limite precisa ser construído. É nesse sentido que, ao comentar o texto freudiano, Hyppolite (1954) afirma que "a distinção entre o estranho e ele mesmo é uma operação, uma expulsão" (p. 899). Essa expulsão, resultado do trabalho da pulsão de morte, funda simultaneamente o externo e o interno ao ego. No entanto, esse momento é ainda muito primário e diferencia apenas um "eu" de um "não eu". A categoria de "objeto" ainda não pode ser aplicada ao que é expulso do ego (Green, 1993/2010).

O juízo de existência ocorre num momento posterior ao juízo de atribuição, sendo interesse do ego-realidade definitivo, desenvolvido a partir do ego-prazer inicial. Nesse momento, não é mais o princípio de prazer que rege o funcionamento, uma vez que a realidade já está sendo considerada. O objetivo do juízo de existência é confirmar se algo que existe no ego como uma 
representação pode ser também encontrado na realidade. Dessa forma, o subjetivo corresponde ao interior do ego e o objetivo ao exterior. Nesse juízo, não é mais suficiente apenas saber se o objeto apresenta qualidades boas para ser incorporado, sendo necessário também se certificar de que ele exista na realidade assim como existe na representação, de forma que o indivíduo possa se utilizar dele para se satisfazer (Freud, 1925/2006).

Inicialmente, representação e percepção seriam idênticas, uma vez que a representação se origina da percepção de algo da realidade. No entanto, o pensamento tem a capacidade de trazer à mente a representação de um objeto externo sem que este esteja ainda presente na realidade. É devido a isso que o objetivo do teste de realidade empreendido pelo juízo de existência é "não encontrar na percepção real um objeto que corresponda ao representado, mas reencontrar tal objeto, convencer-se de que ele está lá” (Freud, 1925/2006, p. 267).

Uma condição fundamental para que este teste de realidade seja estabelecido, isto é, para que o ego precise buscar reencontrar um objeto de sua percepção novamente na realidade, é a perda do objeto de satisfação. Em Acaso e Repetição em Psicanálise (Garcia-Roza, 1987), o autor diz que, antes da aquisição da linguagem, a criança está inserida em um "afetivo puro", em que tudo é apenas afirmação, expressão direta de um pulsional. Portanto, esta é a maneira inicial de relação entre a criança e sua mãe. Se toda vez que sentisse fome, o seio lhe fosse sugerido, seria impossível para a criança diferenciar seu próprio corpo do de sua mãe. O ego-prazer inicial, regido pelo principio de prazer, não pode assim reconhecer a realidade externa. A ausência da satisfação é extremamente necessária para que, desiludida, a criança seja forçada então a reconhecer o seu exterior e a buscar maneiras outras de encontrar a satisfação.

De acordo com Garcia (2010a), “a constatação de que o apelo é indispensável para que a necessidade seja atendida é fundamental para o rompimento do sentimento de inclusão totalizadora do eu e contribui para a formação de um primeiro limite interno/externo" (p. 33). Dessa forma, a negação possibilita ao sujeito ir ao encontro de objetos reais no mundo. A partir disso, o aparelho psíquico instaura um novo modo de funcionamento: o princípio de realidade. Mezan (2013) afirma que, a partir da instauração desse 
princípio, a realidade exterior passa a ser um fator regulador da atividade psíquica, uma vez que daí nasceria o próprio pensamento e "todas as atividades mentais cuja energia de funcionamento é derivada da renuncia provisória da satisfação" (p. 157). Como consequência, o ego-prazer inicial dá lugar ao egorealidade definitivo, que é um ego capaz de suportar o adiamento da descarga até reencontrar o objeto no mundo externo, mesmo que este objeto seja sempre insatisfatório (Figueiró, 2002).

Portanto, o sujeito é, de acordo com Garcia-Roza (1987), resultado da negação da pura afirmação, negação essa que tem que ser exercida pelo exterior. Da mesma forma que é o objeto materno que oferece o seio no início da vida, o que funda a relação amorosa e a coloca como elemento intermediário de uma nova série, é esse mesmo objeto que precisa recusar à criança o seio, frustrando assim sua satisfação. Nas palavras do autor, "essa dupla separação a da criança em relação ao seio e a da mãe em relação ao filho - é sugerida por Freud como sendo devida à ação da pulsão de morte enquanto princípio de disjunção" (Garcia-Roza, 1987, p. 79).

A conclusão, então, é de que uma diferenciação entre interno e externo, ou entre subjetivo e objetivo, não existe desde o início. A negação é a disjunção que resulta na primeira diferenciação interno/externo. Segundo Hyppolite (1954), “a negação vai desempenhar um papel, não como tendência para a destruição, nem tampouco no interior de uma forma de juízo, mas como atitude fundamental de simbolicidade explícita" (p. 901). Uma vez que o motor dessa negação é a pulsão de morte, esta se caracteriza como a responsável pela separação entre a criança e a mãe, e, consequentemente, pela constituição do psiquismo e do objeto. Saímos aqui de uma interpretação puramente negativa de tal conceito. Para Garcia-Roza (1987), “o que temos aí articulados são pares de opostos complementares: interior-exterior, introjeção-expulsão, afirmaçãonegação, fusão-desfusão, pulsão de vida-pulsão de morte" (p.77).

A Negativa (Freud, 1925/2006), trabalho cuja questão central é a construção da externalidade, nos mostra que tanto o juízo de atribuição quanto o juízo de existência contribuem para que os limites entre interno e externo comecem a ser delineados, o que resulta na criação simultânea do ego e do objeto. A ação intelectual de julgar alguma coisa se constitui como a continuação desse processo original através do qual o ego-prazer inicial 
introjeta o que é bom e expele o que é mau. Freud (1925/2006) compara a polaridade afirmativa/negativa com que julgamos as coisas à oposição entre os modos de funcionamento das pulsões de vida e de morte. Dessa forma, "a afirmação, como um substituto da união - pertence a Eros; a negativa - o sucessor da expulsão - pertence ao instinto de destruição" (Freud, 1925/2006, p. 269).

O que vemos aqui é não somente a separação entre intelectual e afetivo, como afirmamos acima, mas sim a gênese do intelectual a partir do afetivo, ou seja, as raízes pulsionais do pensamento. É para isso que Hyppolite (1954) aponta ao nos dizer que a denegação "tem a verdadeira função de gerar a inteligência e o próprio posicionamento do pensamento" (p. 896). Para o filósofo, Freud (1925/2006) encontra a gênese do pensamento no negativismo, e esse é um dos pontos que Green (1993/2010) aprofundará com a sua teorização sobre o trabalho do negativo. 


\section{3 \\ O trabalho do negativo estruturante}

Segundo Green (2002/2008), o artigo A Negativa (Freud, 1925/2006) justifica, por si só, a necessidade de se pensar sobre o trabalho do negativo. Se em Freud (1925/2006) vimos o início de uma teorização sobre as raízes pulsionais do intelectual, na obra de Green (1982/2003, 1993/2010) veremos como a questão do pensamento, articulada à negatividade, se torna central. $\mathrm{O}$ autor encontra na obra de Freud pontos que o ajudam a sustentar sua própria noção de trabalho do negativo, e afirma que traços do negativo estiveram presentes desde o início da psicanálise, mesmo que não tenham recebido esse nome. Inclusive, a própria ideia de "trabalho" já está presente na obra freudiana, com as noções de "trabalho do sonho" e de "trabalho do luto" (Green, 1993/2010).

Exemplos como "o luto e a perda do objeto, evidentemente, as representações por suas relações com a pulsão, as identificações por suas relações com o desejo, e, last but not least, o imenso continente da pulsão de morte" (Green, 2002/2008, p. 260) apontam, de acordo com Green (2002/2008), a presença da negatividade na teoria psicanalítica. O autor afirma que a ideia do negativo pode esclarecer melhor muitos conceitos freudianos, tais como a identificação e a sublimação, e que também autores como Bion e Winnicott se referem a essa ideia, mesmo que sem nomeá-la.

No entanto, é na obra de Green (2002/2008, 1993/2010) que uma teorização profunda e rica se deu acerca do tema da negatividade, que passou de adjetivo na psicanálise para substantivo em sua obra. A partir do conceito de trabalho do negativo, poderemos pensar a importância da ação da pulsão de morte, definida como motor desse trabalho, na constituição psíquica, uma vez que os movimentos que esta põe em curso propiciam tanto a negativação das pulsões quanto a do objeto primário, inserindo assim a diferença e a separação necessárias entre mãe/bebê que têm como resultado a estruturação do aparato psíquico e a delimitação do duplo limite que o organiza, bem como a emergência da atividade representacional e do desejo, possibilidades de qualquer criação psíquica (Green, 1982/2003, 1993/2010). 


\section{1}

\section{A pulsão de morte como motor do trabalho do negativo}

De acordo com Candi (2010), a noção de negativo se inicia na teorização de Green nos anos 1960. Essa teorização abarca desde o extremo onde se encontra o recalque até o extremo do irrepresentável, o que indica que o negativo se refere, sobretudo, à questão do trabalho da representação. Podemos defini-lo, na verdade, como o que está no limite da representação, podendo tanto se manifestar como efeito do inconsciente e como o que põe o trabalho psíquico em movimento, quanto como excesso que se torna destrutivo e desorganizador (Candi, 2010).

Num primeiro momento, Green (2002/2008) define o trabalho do negativo como o conjunto dos diferentes mecanismos primários de defesa, tais como: o recalque, a forclusão, a negação, a clivagem e a rejeição. Todas essas defesas apresentam o mesmo objetivo, que é possibilitar o julgamento e a escolha, ou seja, dizer sim ou não ao pulsional. Dessa forma, esse mecanismos negativizam o pulsional que busca a satisfação imediata através da descarga. Essas defesas são o cerne do trabalho do negativo no que se refere ao funcionamento do eu, mas esse trabalho se estende também para a esfera do objeto, como veremos adiante.

Ao colocarem em andamento o circuito de expulsão/reintrojeção, tais defesas se caracterizam como constitutivas do psiquismo, pois movimentam a ação de delimitação entre o dentro e o fora que possibilita a constituição dos limites egóicos. Ao expulsar os excessos ameaçadores da vida, esse conjunto de defesas possibilita o trabalho psíquico e a atividade representacional, que terão como consequência a possibilidade de desejar e de pensar. $\mathrm{O}$ trabalho do negativo se caracteriza, portanto, como um trabalho de morte, mas que preserva a vida. Sua consequência última é a delimitação do duplo limite que, na concepção de Green (1982/2003, 1993/2010), constitui o próprio psiquismo e suas fronteiras.

Em A Negativa (Freud, 1925/2006), Freud encontra a origem da negação na pulsão de morte, o que o faz concluir que esta pulsão pode assumir a função de negação. É a partir disso que Green (2001) afirma que as defesas primárias, que se caracterizam todas como formas de dizer não ao pulsional e 
de evitar as tensões desprazerosas, trazem a marca da pulsão de morte. De acordo com o autor, o trabalho do negativo incide sempre sobre algum grau de recusa e não pode ser concebido sem sua relação com a pulsão de morte, motor desse trabalho (Green, 2001).

Se faz necessária então uma introdução sobre o pensamento do autor sobre as pulsões de vida e as pulsões de morte. Dialogando com autores que priorizam em suas teorias a pulsão ou o objeto, Green (1990) afirma que a questão de ter que escolher entre um ou outro é, na realidade, um falso dilema, uma vez que ambos são fundamentais na constituição psíquica e não podem ser estudados sem a relação que estabelecem entre si. Isto porque o objeto é o revelador das pulsões. É através da relação com o objeto, e mais ainda quando este falta e não satisfaz a pulsionalidade, que a pulsão pode ser reconhecida e fazer sentir seus efeitos (Green, 1990). Assim, o objeto possibilita que a pulsão se mostre, mas é pela ação da pulsão que um objeto é constituído como tal.

A relação entre pulsão e objeto apresenta importante papel também na teorização de Rosenberg (2003). Em Masoquismo Mortífero e Masoquismo Guardião da Vida (Rosenberg, 2003), o autor afirma que a intrincação pulsional se dá pelo intermédio do objeto e que este é, inclusive, imprescindível para que aquela aconteça e seja revelada. De acordo com o autor, na intrincação as pulsões permanecem, na realidade, homogêneas, mas misturando na relação com o objeto seus efeitos homogêneos que provocam, por sua vez, um resultado em comum. Isto significa que ambas as pulsões apresentam uma função importante na constituição do objeto. A ligação promovida pela pulsão de vida é essencial para que o objeto possa apresentar uma coerência e unidade, impedindo, assim, que a pulsão de morte o despedace.

Por outro lado, a ação da pulsão de morte possibilita o estabelecimento das diferenças internas que promoverão a estruturação complexa que enriquece o objeto, bem como a relação com o mesmo. Dessa forma, “a intrincaçãodesintrincação, deixando uma parte de ação à pulsão de morte, introduz uma variedade-diversidade não somente no interior do objeto, mas, pouco a pouco, no conjunto do mundo objetal” (Rosenberg, 2003, p. 163). A ação da pulsão de morte se exprime aqui a partir da desintrincação pulsional e, dependendo do seu grau, tal desintrincação tem efeitos patológicos ou positivos. Dentre os 
positivos, Rosenberg (2003) aponta para o importante papel da pulsão de morte na constituição psíquica, uma vez que além de promover a diferenciação do objeto, sua ação também incide sobre as divisões e separações necessárias dentro do próprio psiquismo, tornando-o, portanto, ao mesmo tempo "unitário e diferenciado" (Rosenberg, 2003, p. 167).

É também a partir da correlação e complementaridade entre objeto e pulsão que Green (1993/2010) faz sua contribuição à teoria das pulsões. Para o autor, a definição das funções da pulsão de vida e da pulsão de morte como sendo, de acordo com Freud (1923/2006) e respectivamente, a ligação e o desligamento, a conjunção e a disjunção, está correta, mas insuficiente. $\mathrm{O}$ investimento implica numa ligação e o desinvestimento, por sua vez, num desligamento, e tanto a ligação quanto o desligamento incidem simultaneamente nos fenômenos psíquicos e na relação com o objeto externo. Do mesmo modo, a forma reflexiva de ligação, referente à que acontece no narcisismo, é também uma forma de ligação com um objeto (Green, 2001).

No entanto, Green (2001) não estabelece uma relação direta da ligação com a pulsão de vida e do desligamento com a pulsão de morte, uma vez que as unidades promovidas por Eros se constituem tanto de ligações quanto de desligamentos. Mas, uma vez que não podemos pensar a sexualidade sem a ideia de ligação e tampouco de objeto, mesmo que seja no narcisismo, a pulsão de vida, que abarca a pulsão sexual, é referida à ligação ao objeto (Green, 1990, p. 75). Dessa forma, mais do que ligar, a meta das pulsões de vida é garantir a função objetalizante, o que significa transformar em objetos as estruturas ou até mesmo o que não apresenta as qualidades de objeto. Uma vez constituído tal objeto, este é passível de ser investido tanto pelo amor quanto pelo ódio. No entanto, a função objetalizante não se refere somente ao objeto do investimento em si, mas deve também ser estendida ao próprio investimento como processo psíquico. É a capacidade de estabelecer investimentos significativos, de forma que o próprio investimento é objetalizado. Enquanto houver investimento, haverá o predomínio da libido (Green, 1983/1988, 2001).

O objetivo maior da objetalização das pulsões de vida é, mediante a função sexual, promover a simbolização, "processo psíquico com perspectivas infinitas" (Green, 1993/2010, p. 92) que presume a ligação de várias representações, sendo ela própria uma forma particular de ligação. Esta 
realização garante que as pulsões de vida e as pulsões de morte continuem intrincadas, o que é indispensável para o funcionamento do aparelho psíquico. O inconsciente aparece então como "a organização mais preservadora da função objetalizante" (Green, 1993/2010, p. 102), uma vez que o próprio conceito supõe uma rede de representações, ou seja, um campo no qual as relações estão presentes.

Por sua vez, a pulsão de morte "além de procurar ser descarregada indiscriminadamente, age como uma força que se opõe à realização de investimentos significativos e que, portanto, resiste em ser objetalizada" (Candi, 1993/2010, p. 252). Dessa forma, mais do que desligar, a meta das pulsões de morte é garantir a função desobjetalizante. O resultado de tal desobjetalização pode ser a desqualificação do objeto no sentido de este não mais ser concebido como um semelhante e poder, dessa forma, ser alvo de qualquer tipo de destrutividade por parte do sujeito, desde a indiferença até a agressão. É como se a alteridade do objeto pudesse deixar de ser reconhecida, assim como seus direitos (Green, 1993/2010). De acordo com Green (1990),

a pulsão de morte entra em ação cada vez que o sujeito realiza, diante do objeto, uma desqualificação de sua própria singularidade e de seus próprios atributos: seja quando o objeto se torna anônimo, como o objeto da perversão, por exemplo; ou quando o objeto é despojado de suas características de ser que sente e pensa, como no caso da tortura; ou então o objeto é desprovido de sua identidade humana, e são as mil maneiras pelas quais se exercem as formas de segregação social e até mesmo psiquiátrica (p. 76)

A função desobjetalizante se refere ao desinvestimento dos laços com o objeto, mas pode se estender também para o eu e para o próprio investimento, uma vez que este sofreu um processo de objetalização. A pulsão de morte se encontra nas duas extremidades do psiquismo, sua base sendo a pulsionalidade destrutiva e o seu "pico" sendo o masoquismo moral (Green, 1993/2010). Em sua forma mais extrema, essa pulsão põe em ação o narcisismo negativo que, ao contrário de um narcisismo positivo que visa a unificação egóica, aspira ao nível zero de tensão, ao nada, à não-vida. Para Green (1983/1988), o movimento narcísico se caracteriza por essa orientação para a redução radical das tensões.

Podemos pensar o narcisismo negativo como a busca de independência de um objeto que provoca tensões ou, mais ainda, a defesa contra um outro que 
ameaça a integridade do ego, como veremos no capítulo seguinte. No limite, como acontece no caso de uma desobjetalização radical, o narcisismo negativo visa à anulação do outro e até de si mesmo, sendo "uma espécie de medida extrema, a qual, após ter desinvestido os objetos, se transporta, se tiver necessidade, sobre o próprio Ego, e o desinveste. " (Green, 2002/2008, p. 271). O ego então se empobrece e esvazia, perdendo sua identidade, coesão e organização.

Para Green (1993/2010), o conflito objetalização/desobjetalização parece ser o central no aparelho psíquico, e a oscilação entre ambas as funções é o que constitui o funcionamento psíquico normal. Segundo Carvalho e Viana (2012), tais oscilações vão "de um polo, que vai do amor de objeto à sublimação, a outro, onde a regressão revela uma substituição dos investimentos de objeto por investimentos narcísicos provenientes do objeto" (p. 46). Isto significa que o psiquismo é movimentado por alternâncias entre a intrincação e a desintrincação pulsional. Enquanto os fenômenos psíquicos forem caracterizados por essa alternância, é ainda a intrincação que prevalece, uma vez que as desintrincações se dão de forma parcial e momentânea, sendo seguidas por novas ligações. Nos casos em que há o predomínio da pulsão de morte, o que prevalece é o desligamento, como veremos adiante (Green, 2001).

Portanto, a pulsão de morte é o motor da desobjetalização realizada pelo narcisismo negativo, sendo ele próprio uma forma radical de expressão do trabalho do negativo (Green, 2002/2008). Nas palavras de Garcia (2010a), esta função desobjetalizante "age no sentido da ruptura e do desligamento, isto é, da negação. É neste sentido que o trabalho do negativo se insere no escopo da função desobjetalizante, já que em suas diferentes manifestações se apresenta sempre como uma forma de negação" (p. 39). Em suma, o trabalho do negativo instaurará um não que vai possibilitar a diferenciação e o estabelecimento de um duplo limite: o limite entre o interno e o externo e o limite entre as instâncias psíquicas. Dizer "não" é, portanto, estabelecer os limites constitutivos do psiquismo, que "possibilitam a atividade representacional" (Garcia, 2010a, p. 38). 


\section{2 \\ 0 duplo limite}

Green (1990) propõe que o próprio limite seja definido como um conceito e afirma que essa noção está presente em toda obra de Freud. Inclusive, toda a concepção greeniana sobre o aparato psíquico está articulada à questão dos limites. A capacidade do psiquismo de se movimentar e sua própria funcionalidade dependem do estabelecimento do duplo limite, constituído por duas áreas fronteiriças (Green, 1982/2003). O primeiro limite delimita o dentro e o fora do sujeito, ou seja, o seu mundo psíquico e a realidade externa. O segundo limite, que pode ser comparado ao préconsciente, é a barreira que separa o consciente do inconsciente funcionando, de acordo com Candi (2010), “como uma pele interna para a vida fantasmática do inconsciente" (p.200). O bom estabelecimento desse duplo limite é o que permite a estruturação do psiquismo e a organização tempo/espaço.

O interessante nesta concepção é não somente a divisão de dois espaços diferentes propiciada pelo limite, mas também a comunicação e as trocas que acontecem entre esses espaços distintos. Na teorização de Green (1990), o limite é postulado não somente como uma fronteira, mas como o território a partir do qual são produzidas as transformações no aparato psíquico. Dessa forma, o limite produz um corte que é aqui interpretado como o que inicia a organização psíquica e do mundo, se caracterizando como o momento primeiro de distinção do objeto primário. Green (1990) postula o psiquismo como uma formação intermediária entre o corpo e o mundo, e encara o diálogo entre o somático e o real como brutal, uma vez que as exigências do corpo são imperiosas. Para o autor, "se não dispuséssemos dessa formação amortecedora dos choques, que é constituída pelo psiquismo inconsciente e pelo psiquismo consciente, estaríamos ainda, provavelmente, num estádio pré-hominiano" (Green, 1990, p. 59).

É exatamente o modo como se dá a relação com o objeto primário que engendra movimentos objetalizantes ou desobjetalizantes, funções das pulsões de vida e de morte, respectivamente. Green (1993/2010) nos diz que a grande novidade da psicanálise contemporânea, em relação a Freud, é a teorização acerca do objeto. Segundo o autor, alguns pacientes mostram que pensar 
somente o jogo pulsional é insuficiente para compreender a problemática que apresentam. Nesses casos, o objeto se apresenta como um importante fator de interferência na constituição da subjetividade. Tal interferência causa ruídos nos chamados pacientes limite, e pode ser notada justamente por ser efeito de um objeto primário que não pôde cumprir suas funções, como veremos adiante.

O trabalho com tais pacientes, cujos sintomas denunciam relações excessivas com um objeto primário que não pôde ser elaborado, fez Green $(1983 / 1988,1993 / 2010)$ se debruçar profundamente sobre a questão da relação com o objeto, que podemos articular às questões do trabalho do negativo, do duplo limite, da simbolização e do pensamento. O objeto primário tem, para Green (1983/1988, 1993/2010), papel primordial na constituição psíquica, o que o faz chamar de "objeto absolutamente necessário". Esse objeto, responsável pela estruturação do espaço psíquico, continuará necessário por toda a vida. Dentro dessa concepção, uma de suas funções é propiciar a intrincação da libido e da destrutividade, o que significa que a relação com o objeto pode evitar uma ativação exagerada da pulsão de morte. O que fica claro a partir da leitura da obra de Green (2001, 1993/2010) é que a ação desta pulsão depende em grande parte da relação estabelecida com o objeto materno.

É a partir da resposta do objeto à demanda de satisfação pulsional que a criança conseguirá percebê-lo como fora de si e construir suas fronteiras egóicas. No início da vida, a indiferenciação do bebê inclui sua mãe, que é como uma parte do seu id. No momento inicial, o que acontece é uma alternância entre momentos de fusão e momentos de separação. Portanto, a constituição do ego do indivíduo é simultânea à perda da mãe, e a diferenciação ego/id acontece conforme o bebê vai se diferenciando do objeto primário. A ideia de Freud em A Negativa (1925/2006) de que a perda do objeto de satisfação é condição para o estabelecimento do teste de realidade e, portanto, para a diferenciação entre interno e externo é reafirmada e aprofundada a partir da teorização sobre o trabalho do negativo.

Para Green (1993/2010), ao pensar nos efeitos dessa falta, a psicanálise se associa diretamente à ideia do negativo. A realização alucinatória do desejo pode nos dar indícios do trabalho psíquico realizado a partir desse desejo insatisfeito. Nas palavras do autor: 
A sequência experiência de satisfação-traço dessa experiência-pausaressurgimento da necessidade-reinvestimento dos traços da experiência de satisfação (desejo)-realização alucinatória do desejofracasso dessa realização alucinatória-sinais de desamparo-retorno do objeto que proporcionou a satisfação e nova experiência de satisfação, apesar de seu caráter esquemático, ajuda a compreender de imediato o sentido do trabalho do negativo (Green, 1993/2010, p. 70)

Este trabalho não apenas atenua a falta em questão, mas também demonstra que os traços inscritos no aparelho psíquico não são rígidos e inertes, podendo ser despertados de novo e se modificar, se enriquecendo, se deformando ou se reorganizando dentro do aparato. $\mathrm{O}$ que anima todo esse esquema são as pulsões, essas sempre capazes de dar origens a novos desejos. Como a sua satisfação não pode ser imediata e nunca completa, este é o momento de ação do trabalho do negativo (Candi, 2010).

O desejo é esse movimento que reinveste traços de uma experiência anterior de satisfação. O movimento desejante é, portanto, a reativação intrapsíquica da inscrição de uma experiência intersubjetiva. Dessa forma, Green (1993/2010) nos diz que as representações inconscientes já são resultado de uma negativação do pulsional proporcionada pelo trabalho do negativo. Isto porque antes de se tornar movimento desejante, a pulsão encontra apenas um "espaço vazio", que suscitará um trabalho psíquico representacional, uma vez que essa demanda pulsional imperiosa deve ser negativada, devido a impossibilidade de sua satisfação total. É por isso que Green (1993/2010) afirma que o negativo já implica a "estrutura bifacial" do sintoma, ou seja, desejo E defesa.

A representação é o primeiro destino dessa pulsão que não pode obter a satisfação imediata, destino este que se apresenta como um recurso psíquico para lidar com a frustração. Na Carta 52 (Freud, 1886a/2006), vemos que as impressões devem ser inscritas em traços mnêmicos para que depois sejam representados, processo que complexifica o aparato psíquico e possibilita que este encontre formas substitutas para se satisfazer. A renovação constante do movimento do desejo assegura a progressão da organização psíquica. No entanto, para que haja a inscrição de traços da experiência que possam ser reativados em caso de necessidade, é preciso que experiências de satisfação na relação com o objeto tenham ocorrido de forma repetida o suficiente para 
construir uma inscrição de referência prazerosa, sem desprazer ou angústia. Como afirma Green (1993/2010):

A realização alucinatória do desejo se apoia, de algum modo, na atividade pulsional sempre em busca de satisfação. O papel de quaseobjeto que a realização alucinatória do desejo oferece à psique nos conduz a ressaltar essa dependência da constituição de objetos imaginários ao objeto primário real que evoca a realização alucinatória do desejo. Assim, se é necessário fazer intervir no nível do sujeito a estrutura pulsional que impulsiona à criação dessas formações, esta, não esqueçamos, repousa sobre os traços de experiências reais que supõem a ação de um objeto real (p. 197).

A falha da resposta do objeto à demanda de satisfação do sujeito é fator importante para que o teste de realidade aconteça, para que uma primeira diferenciação comece a se dar e para que o mundo externo seja levado em consideração. Isto porque, ao perceber que a realização alucinatória não cessa, de fato, a demanda pulsional, a criança é forçada a reconhecer a exterioridade e a buscar na realidade objetos outros de satisfação. Esse reconhecimento da realidade é concomitante ao "surgimento" do psiquismo individualizado da criança. Dessa forma, é necessário que se insira uma negação, um limite, entre a mãe e o bebê para que esse contorno egóico possa começar a ser estabelecido. Como já vimos, essa negação é produto da ação da pulsão de morte (Freud, 1925/2006; Garcia-Roza, 1987).

A partir de A Negativa (Freud, 1925/2006), vimos que, ao inserirem as dicotomias bom/mau e existente/não existente, os juízos de atribuição e de existência proporcionam a primeira delimitação entre o que é interno e o que é externo. Green (1993/2010) afirma que o que chama de "excorporação", esse movimento de "cuspir" o que é mau, não supõe um objeto no espaço que recolhe o que foi expulso, uma vez que ainda não há diferenciação eu/objeto. No primeiro momento, ainda não há objeto, sendo apenas uma questão de se lançar no espaço o que não é desejado, de forma que os excessos são jogados de modo indiscriminado para o exterior. Entretanto, esse movimento de excorporação tem, como consequência, a delimitação da primeira diferenciação dentro/fora. Essa expulsão é o que possibilita a constituição de um espaço interno que pode se organizar como tal, e que assim reconhece uma exterioridade separada de si. De acordo com Candi (2010), o objeto é apreendido de forma mais integrada a partir da integração do sujeito. 
Em consonância com esta ideia, Rosenberg (2003) afirma que, quando o objeto causa desprazer ao sujeito, é a pulsão de morte que é projetada sobre ele, forma que o ego encontra de se desfazer da mesma. De acordo com o autor, a polarização descrita por Freud em A Negativa (1925/2006) é a polarização entre o que foi projetado da pulsão de morte no exterior e a libido narcísica que investe o ego. Posto que este primeiro momento é de indistinção mãe/bebê, esta polarização opera a primeira distinção, uma clivagem primária, entre o sujeito e o objeto, entre o dentro e o fora. A partir disso, Rosenberg (2003) também afirma que é a polarização pulsional, "mecanismo fundamental do desligamento-desintrincação pulsional" que promove a diferenciação entre interno e externo (Rosenberg, 2003).

De acordo com Figueiredo e Cintra (2004), o trabalho do negativo transforma aqui o caos, no qual não há objetos nem ordem, em algo mais simples, como objeto bom ou mal. Tais objetos são desde o início resultado desse trabalho e, portanto, produtos da fantasia, uma vez que, rigorosamente falando, "não há objetos em primeira instância, há caos. Os objetos já nascem do trabalho do negativo ao cindir bom e mau e ao projetar tais qualidades sobre partes mais ou menos circunscritas do ambiente, objetivando-as com base nestas experiências afetivas discriminadas e opostas" (Figueiredo \& Cintra, 2004, p. 30).

Além disso, é importante destacar que o objeto considerado "mau" o é não por uma característica intrínseca ao mesmo, mas devido a uma ausência ou a uma falha. No entanto, neste momento primitivo de constituição psíquica, tal ausência não pode ainda ser representada, o que faz com que o objeto seja considerado como objetivamente mau. Da mesma forma, o objeto bom se constrói a partir da negação de suas falhas e ausências, sendo, portanto, idealizado. De acordo com Figueiredo e Cintra (2004), “o bom e o mau circunscrevem-se como 'objetos' pela recusa e desmentido de tudo o mais que a experiência comporta, sendo eles mesmos, em sua condição purificada, “inexistentes"' (p. 30).

O mecanismo da excorporação dá indícios de que o aparelho psíquico apresenta recursos para se livrar do que é sentido por ele como mau. Dessa forma, o psiquismo constantemente expulsa partes de si para sobreviver. É por isso que se pode dizer que este é um trabalho de morte, uma vez que são partes 
do próprio aparato que são projetadas para fora (Candi, 2010). A partir dessa expulsão e da incorporação, que é seguida pela introjeção, o Eu-prazer purificado, "núcleo estrutural do psiquismo, cuja constituição é pré-requisito para toda evolução" (Green, 1993/2010, p. 196) é constituído. No entanto, para que esse Eu-prazer purificado seja instaurado, é necessário que ele se apoie nos cuidados maternos.

$\mathrm{Na}$ realidade, todo esse processo depende da resposta do objeto. Nos casos em que este cumpre suficientemente bem suas funções, possibilita o estabelecimento da realização alucinatória do desejo, que está na origem da neurose e do sonho. Isso supõe um vínculo com o objeto baseado no amor e na esperança, o que possibilita a substituição do objeto primário por outros objetos substitutos, assim como o conhecimento e a aceitação do proibido (Candi, 2010).

Green (1982/2003) afirma que, ao falar da diferenciação entre o dentro e o fora em A Negativa (1925/2006), Freud não menciona o segundo limite que divide o interior. A expulsão que coloca do lado de fora o que é considerado ruim não é suficiente para resolver a questão. É preciso ainda dominar o retorno dessas impressões dolorosas, o que justifica a necessidade do mecanismo do recalque, que tem como consequência o limite entre as instâncias psíquicas. Tal mecanismo não é operante desde o início da vida.

Dessa forma, o segundo limite constitutivo do psiquismo é formado a partir de diversas repetições do processo de reintrojeção do que foi evacuado. Estes conteúdos evacuados pela expulsão, primeira forma do trabalho do negativo, devem poder ser primeiro acolhidos pelo objeto primário e depois devolvidos para a criança, que poderá assim acolher os conteúdos no psiquismo através do recalque. Pela instauração do recalque, o trabalho do negativo desdobra o limite interno/externo em limite consciente/inconsciente. Green (1993/2010) destaca o recalque como dispositivo estruturante do psíquico, uma vez que instaura uma espécie de segundo mundo externo ao dar origem ao "recalcado organizador do inconsciente" (p. 76). Segundo o autor,

Isso permite, pela primeira vez, falar não apenas de um processo da negatividade, mas de uma negatividade constituída, que logo assumirá a forma de uma negatividade instituída. Pode-se captar, aqui, a primeira conjunção de dois grandes sentidos do negativo: o negativo como desprazer ou como contrário do prazer e o negativo como 
duplicação da experiência positiva buscada: realização alucinatória do desejo e de fantasias (Green, 1993/2010, p.77).

É importante ressaltar que o trabalho do negativo acontece num movimento dialético. Uma vez que, ao constituir um outro espaço, o estabelecimento dos limites psíquicos constitui uma diferença, isto implica também na perda do ilimitado característico da indiferenciação mãe/bebê. A solução para lidar com tal inconveniente é garantir a segurança e a manutenção dos dois territórios separados, de forma que a diferenciação do objeto primário permita a comunicação entre ambos os espaços (Green, 1983/1988). Isto significa que o primeiro e o segundo limites que constituem o aparato psíquico devem interagir entre si, de forma que as representações circulem. $\mathrm{O}$ primeiro limite interno/externo só se mantém se articulado ao segundo limite.

O segundo desdobramento permite a abstração necessária para que aconteça o pensamento, uma vez que o recalque promove um afastamento das fontes pulsionais, afastamento que é fundamental para o processo de pensar. Como veremos adiante, esse afastamento necessita da negativação do objeto primário. Além disso, a tarefa do pensamento parece paradoxal, pois, se de um lado esse afastamento das fontes pulsionais é necessário, de outro, o pensamento não deve se distanciar totalmente de suas origens, pois são estas que lhe dão o seu peso de verdade (Green, 1982/2003). Candi (2010) nos diz que, no modelo metapsicológico do duplo limite, o processo do pensamento se dá na intersecção das linhas instituídas por este limite. Isto significa que este processo acontece na intersecção entre o interno, do trabalho intrapsíquico, e o externo, do trabalho intersubjetivo, possibilitando por isso uma articulação entre esses dois eixos.

O espaço interno que resulta da organização do duplo limite tem sua consistência devido ao surgimento das representações e do pensamento. A tarefa fundamental do aparato psíquico é a de realizar as representações, tanto do mundo externo quanto do mundo interno. Candi (2010) afirma que essa tarefa é, na realidade, dupla, uma vez que ela se caracteriza pela construção das representações do que deve ser representado e também pela representação da atividade psíquica do aparato. O que parece claro é que o psiquismo deve "criar" essa capacidade de representar o que o cerca e a si mesmo. 
A possibilidade de suportar a ausência e a consequente perda do objeto primário é o que promove, a princípio, essa atividade representativa. Representar é já uma forma de ligação e, posteriormente, os processos de pensamento ligam tais representações de forma não especular (Green, 1982/2003), de maneira que o objeto possa ser pensado. O que podemos observar, nesse caso, é a preservação da função objetalizante, uma vez que as produções psíquicas possuem relações entre si. O funcionamento psíquico normal, garantido por essa função, se baseia então nas correspondências que permitem o trânsito das formações psíquicas. Tais correspondências podem ser relações de oposição, mas também de colaboração, o que permite a aparição do conteúdo latente a partir do conteúdo manifesto correspondente (Candi, 2010).

Todo esse mecanismo dá conta das capacidades de integração e de organização do próprio psiquismo. Porém, é necessário levar em consideração a dimensão aleatória do objeto que é, de acordo com Green (1993/2010), “a dimensão mais incontrolável da conjuntura" (p. 77). O que fica claro é que o objeto externo não está à completa disposição do ego que, dessa forma, tem que ir até o objeto e constantemente se reajustar. Isto porque o objeto tem seus próprios desejos, seus próprios objetos, seu próprio tempo, tudo o que não necessariamente coincide com o que o ego deseja. O objeto é, portanto, fonte de desequilíbrio para o ego (Green, 1983/1988).

Se, por um lado, esse objeto é externo ao psiquismo, por outro ele é constitutivo do mesmo, "sob o duplo estatuto de componente da montagem pulsional e das representações a partir de traços mnésicos" (Green, 1993/2010, p.77). Portanto, se o aparato psíquico teve que buscar recursos para lidar com a ausência da satisfação, deverá encontrá-los para lidar também com a imprevisibilidade do objeto. Green (1993/2010) nos diz que “a estrutura psíquica deve, portanto, encontrar uma solução especificamente orientada pela relação com o objeto" (p. 77).

\section{3}

\section{A função constituinte do "objeto absolutamente necessário"}

A representação do objeto primário é o que garante sua presença intrapsíquica, que pode ser organizadora ou desestruturante. Segundo Green 
(1993/2010), "fazendo parte da montagem da pulsão, o objeto se torna um guia indispensável das representações-meta" (p.78). Isto porque, ao se ligar aos traços mnésicos das experiências anteriores, leva o aparelho psíquico a se orientar em relação ao que deve ser buscado ou evitado, em função dos polos prazer/desprazer. Ao se constituir em uma representação, essa organização oferece o suporte da elaboração psíquica possível.

A questão com os pacientes limite está relacionada a uma dificuldade em manter o duplo limite justamente em decorrência da relação com um objeto primário que não foi negativado, o que tem como consequência um psiquismo que apresenta dificuldades de representar e de pensar. Para que se deem as representações e o próprio pensamento, o trabalho do negativo tem que incidir tanto sobre o objeto quanto sobre as pulsões, constituindo assim o duplo limite do psiquismo. Caso contrário, “ambos os limites tornam-se muito precários e os dois parâmetros - 'bom e mau' e 'real e imaginário' -, em vez de se articularem, confundem-se e se potencializam" (Figueiredo \& Cintra, 2004, p. 32). A partir daí, pode-se criar um mundo em que o que existe é totalmente mau e o que não existe é totalmente bom, o que torna ambos absolutos e traumáticos, sendo assim impossíveis de representar. Um tal mundo impossibilita o pensamento.

Assim, é a relação com o objeto que determinará se o trabalho do negativo constituirá ou ameaçará o aparato psíquico, constituindo ou fragilizando a construção de seus limites. O objeto pode tornar as pulsões toleráveis ou intoleráveis para o sujeito, e Green (1983/1988) afirma que é no primeiro caso que a relação com o objeto pode provocar na criança a sensação de ser amada e possibilitar, dessa forma, a constituição do narcisismo primário e de um ego cuja organização é relativamente estável. Nesse caso, o objeto externo desempenha a função de "espelho, de continente, de Eu auxiliar" (Green, 1983/1988, p. 157), o que resulta que o ego constituído poderá contar com esse objeto ao se defender da pulsionalidade, único conflito que experienciará. É o caso das neuroses clássicas. Dessa forma, Green (1993/2010) articula intimamente o objeto ao trabalho do negativo, dando ao primeiro um papel constitutivo do psiquismo. Para que o objeto cumpra sua função constituinte, é necessário que ele se deixe apagar, se transformando no 
solo psíquico do indivíduo e permitindo, assim, a emergência do desejo e do pensamento.

Qualquer objeto é sempre duplo, pois é, como já vimos, tanto externo quanto interno ao sujeito. Dessa forma, tal objeto é uma construção que apresenta diversas funções. Segundo Candi (2010), essas funções estão no âmbito das pulsões e do Id. Em seu trabalho sobre a concepção greeniana do aparelho psíquico, a autora cita algumas funções que o objeto primário deve desempenhar para promover a constituição psíquica. As funções do objeto seriam: investir o sujeito e se colocar como objeto de investimento; receber esse investimento, transformá-lo e devolvê-lo ao sujeito; estimular a pulsão do sujeito e a construção do enquadre, que possibilitará a criação de sentido e a busca por novos objetos de satisfação; se colocar presente de forma que essa presença possa diminuir o receio do sujeito de perder o objeto definitivamente; dar sustentação ao desejo e viabilizar a criação de novos objetos, o que mantém o investimento libidinal e até aumenta o seu campo; possibilitar a separação e a reunião (Candi, 2010, p. 233).

Todas essas funções agem diretamente no âmbito pulsional, em um momento precoce da constituição psíquica em que os limites egóicos e suas defesas estão sendo estabelecidos. Dessa forma, o excesso ou a falta de alguma dessas funções podem ser experiências traumáticas para o sujeito, aqui diante de duas alteridades: a alteridade intersubjetiva representada pelo objeto, e a alteridade interna, da força pulsional. Algumas dessas funções estimulam a pulsão e a excitação sexual, enquanto outras possibilitam a diminuição da excitação e a contenção da angústia, o que promove o investimento, a objetalização e, por fim, a simbolização. É por isso que o efeito dessas funções do objeto, quando bem realizadas, é bidirecional, uma vez que, por um lado, consegue despertar a excitação num nível médio, movimentando a objetalização que possibilita a simbolização, e, por outro, "alimenta um núcleo autoerótico que permite ao psiquismo ter reservas de prazer" (Candi, 2010, p.234)

O objeto apresenta então uma função paradoxal: é, por um lado, o revelador das pulsões, tendo que estar presente para despertá-las e estimulá-las, mas, por outro lado, precisa também conter essa pulsionalidade, na medida em que deve sustentar os ataques que a criança realizará na tentativa de expulsar os 
conteúdos considerados maus de dentro de si. O mesmo objeto deve se fazer distante o suficiente para que possa ser esquecido, simbolizado e substituído por futuros objetos de investimento. É imprescindível que esse objeto primário falhe e se ausente, para que possa sair do lugar de objeto absoluto para a criança e assim "dar ao indivíduo essa noção capital e essencial segundo a qual é preciso chegar à aceitação do conceito de que há mais de um objeto" (Green, 1983/1988, p. 301).

Dessa forma, além de estimular e também conter a pulsionalidade, funcionando assim como o anteparo da criança, o objeto tem que falhar para que possa ser apagado e perdido, dando lugar a objetos substitutos e ao espaço psíquico interno. Segundo Figueiredo e Cintra (2004), “o luto traz o objeto perdido para a condição que transforma e renova o sujeito - integra-se ao eu e o torna apto a novas ligações" (p. 17). Sendo assim, o objeto absolutamente necessário responde a um movimento pulsional do trabalho do negativo, portanto, da pulsão de morte, ao se deixar apagar. Esse movimento de apagamento tem duas direções: de um lado, através da excorporação, o objeto ocupa lugar no espaço externo, se caracterizando como algo distante e diferente do individuo e, portanto, sujeito a atração ou repulsão. Por outro lado, esse objeto absolutamente necessário é negativado internamente para dar lugar ao vazio estruturante do psiquismo, solo fértil para as representações.

Figueiredo e Cintra (2004) distinguem aqui dois tempos: no primeiro, o objeto tem essa "função pulsionalizante", ao estimular e, assim, despertar os movimentos pulsionais. Paradoxalmente, ainda neste primeiro tempo, o objeto também tem a função de conter essa pulsionalidade. No segundo tempo, está a função do objeto de se distanciar e multiplicar, o que possibilita a busca de novos objetos de investimento, mesmo que estes sejam sempre falíveis. Esse desdobramento em objetos substitutos tem como condição a permanência da presença em potencial do objeto primário, agora internalizado como vazio estruturante e que "é a base da tolerância a todas as distâncias, ausências e inadequações dos objetos substitutivos e, portanto, a base de todos os movimentos desejantes; indo mais longe, é a base de todo pensamento" (Figueiredo \& Cintra, 2004, p. 20).

Esse duplo movimento de negação, no qual o objeto "é negado "para dentro' e negado 'para fora', só é possível a partir de um objeto que sucede em 
sua função de ser um objeto que é "falível e inadequado e assim criando condições para desempenhar seu papel determinante, desde que se entenda que a falibilidade e a inadequação pressupõem um modo muito essencial de estar presente" (Figueiredo \& Cintra, 2004, p. 18). É preciso que o objeto se deixe negativar, que ele permita a existência de uma distância e ausência que poderão ser representadas.

O ego da criança só poderá existir individualmente depois da separação do objeto primordial, separação que deve ser feita de forma gradual. Durante esse processo, ocorrem tanto fases de reunião e dependência do objeto materno, quanto momentos em que "a criança tentará restabelecer, na ausência do objeto, na solidão, o paraíso perdido da fusão" (Candi, 2010, p. 245), ou seja, momentos em que a ausência pode ser suportada, uma vez que a criança começa a criar recursos psíquicos próprios para lidar com ela. Ao longo dessa gradual separação, surgirão sentimentos de frustração e de raiva, concomitantemente a sentimentos de prazer. Dessa forma, haverá experiências ambivalentes e confusas para a criança, nas quais prazer e desprazer podem se misturar.

A partir da presença fidedigna e constante do objeto na realidade externa, objeto esse que suporta os possíveis ataques do bebê e que se deixa falhar, é possível a simbolização de sua ausência. Podemos pensar essa ausência como estando entre a presença e a perda, por isso se caracterizando como uma presença em potencial. Assim, aos poucos e de forma saudável, a ausência do objeto se constitui nessa presença em potencial. Observamos, então, que a construção de um bom objeto interno é condição para que o ego seja constituído com capacidades de ligação que o possibilitarão pensar o objeto fora de si e ter a vivência do sentimento de continuidade que suporta a ausência do objeto e a sua espera. Isto possibilita o seu apagamento e a construção do espaço psíquico, que Green (1993/2010) chama de estrutura enquadrante, espaço do potencial e da ausência.

Para Green (1983/1988), o apagamento do objeto materno e sua transformação em estrutura enquadrante necessitam do suporte de um amor confiável desse objeto. Essa segurança permite, mesmo na ausência da mãe, a garantia de sua presença. A partir disso, o espaço vazio pode ser preenchido pelas fantasias (Green, 1983/1988). Este processo permite um caminho rumo à 
ilusão de independência do objeto, através do enriquecimento do ego. "Ilusão" posto que o sujeito nunca se "livra" realmente desse objeto necessário, uma vez que é ele quem constitui seu psiquismo. $\mathrm{O}$ apagamento do objeto não faz com que o mesmo seja esquecido. Esse objeto absolutamente necessário é assimilado, se transformando no solo psíquico quando o sujeito se apropria dele. E é essa apropriação do outro que nos constitui.

Candi (2010) nos diz que o "objeto total" se decompõe em diferentes partes quando o sujeito se apropria dele. Uma parte desse objeto pode ser assimilada e introjetada no ego a partir das identificações; uma parte se torna o fundamento de todo movimento desejante do sujeito, enquanto uma outra parte permite a substituição dos desejos, possibilitando então a busca de novos objetos; uma de suas partes é inassimilável, o que força o sujeito a aceitar a diferença da alteridade; e, finalmente, "uma parte que serve de suporte para a criação de objetos novos e viabiliza o surgimento de novas funções que possam receber o estatuto de objeto (funções objetalizantes)" (Candi, 2010, p. 235).

Paradoxalmente, a separação do objeto primário só é possível a partir de sua assimilação. Segundo Garcia e Damous (2009), os mecanismos de negativação são fundamentais, pois permitem o apagamento do objeto materno, “o que possibilita o desenho de um espaço psíquico pessoal capaz enfim de comportar as produções subjetivas dentre as quais se situam os processos de simbolização" (p. 108). A estrutura enquadrante se caracteriza, assim, como o estabelecimento da figura interna da mãe, que dessa forma continua presente mesmo quando ausente fisicamente. De certa forma, essa estrutura palia os efeitos da separação do objeto primário. A constituição da estrutura enquadrante acontece como resultado da alucinação negativa da mãe, que promove a construção deste espaço interno a partir do qual surgirão as produções psíquicas.

\section{4}

\section{Alucinação negativa e estrutura enquadrante}

A estrutura enquadrante é constituída a partir de uma alucinação negativa, que se caracteriza pela não percepção de um fenômeno psíquico perceptível. De acordo com Green (1993/2010), “ao a-mais da alucinação 
positiva ('percepção sem objeto') corresponderia o a-menos da alucinação negativa ('não percepção de um objeto')" (p. 178). É preciso lembrar, no entanto, que a alucinação negativa compreende, além da não percepção, a inconsciência dessa não percepção.

Green (1993/2010) aponta para o fato de que o exame da alucinação positiva deve, na realidade, voltar-se para a alucinação negativa. A produção alucinatória é efeito de uma dupla ação: uma face externa, o que significa que uma percepção insuportável sofre uma alucinação negativa na tentativa de negar sua existência; e uma face interna, pois "uma representação inconsciente de vontade (abolida) que procura se tornar consciente, mas que é impedida pela barreira do sistema Cs $(\mathrm{P})$. Ao ceder esta à pressão, o lugar da percepção denegada deixa o espaço vazio" (p. 187). Neste cenário, a percepção insuportável e a representação inconsciente seriam incompatíveis e é a percepção que é invalidada. O espaço que sua alucinação negativa liberou vai ser ocupado, através do mecanismo da projeção, pela representação inconsciente, que se reveste das características de uma percepção.

Assim, a alucinação negativa é uma forma através da qual o ego rompe a relação com a realidade. Isto é possível a partir da retirada de investimento, ou seja, através do desinvestimento que é efeito da atividade da pulsão de morte. Podemos pensar em situações em que essa alucinação negativa acontece de modo isolado, sem que seja seguida de alguma alucinação positiva. Green (1993/2010) afirma que há, em qualquer sujeito, a possibilidade de se utilizar do recurso da alucinação negativa, que se caracteriza por essa retirada de investimento da percepção, sem que isso necessariamente tenha consequências patológicas.

Este mecanismo aponta para a capacidade do aparato psíquico de se utilizar de defesas que interferem até mesmo na realidade externa. Dessa forma, enquanto a alucinação positiva demonstra as possibilidades quase infinitas de transformações que o psiquismo pode produzir, a alucinação negativa dá provas dos múltiplos recursos aos quais o psiquismo recorre "pelo simples pensamento que se contentará em ignorar o mundo ao invés de construir um novo" (p. 207). A alucinação negativa pode ser a defesa a um real que é sentido de forma hostil. 
Green (1993/2010) coloca a alucinação negativa dentro das manifestações do trabalho do negativo, juntamente com o recalque. Enquanto o último está relacionado às representações e aos afetos, a primeira é uma tentativa de se opor ao percebido e "efetua um trabalho que impede o acesso direto à representação como incitação feita ao sujeito de levar em conta uma certa realidade que se diz no discurso do figurável, como ocorrência de um acontecimento psíquico a pensar" (Green, 1993/2010, p. 226). É exatamente para assinalar essa relação "por vir" com o pensamento que a alucinação negativa é definida como representação da ausência de representação.

É importante compreendermos como a alucinação negativa da mãe torna possível a construção das representações, sendo, inclusive, sua própria condição. Na constituição da estrutura enquadrante, a alucinação negativa refere "seu potencial denegador à presença do objeto" (Green, 1993/2010, p. 226). Este não incide somente sobre as representações visuais da presença materna, mas negativizam também dados táteis e cinestésicos que fornecerão a essa estrutura o que lhe permite "segurar" o espaço psíquico e que é remetido ao que a criança sente. Nas palavras de Green (1993/2010),

E é essa mesma impressão - ou esse afeto, como se preferir - que não será "percebida" de forma material figurável, mas fará com que tudo aquilo que se passa no cenário psíquico seja "segurado" junto: ligado e suscetível de criar o ligável. E, certamente, a possibilidade e a inevitabilidade do desligamento estarão incluídas nessa ligação, mas estarão englobando a perspectiva de uma religação possível. Vê-se, então, que a estrutura enquadrante não é percepctível enquanto tal, mas somente através das produções às quais dá lugar o quadro, que permanece silencioso, invisível, "imperceptível" de outro modo que não por referencia à dimensão da latência. Ei-nos confrontados com a aporia das matrizes simbólicas do pensamento (p. 227)

Na concepção do autor (Green, 1982/2003), o pensamento não deriva em uma linha reta da representação. Dessa forma, a alucinação negativa representa o salto do pulsional para o intelectual, sendo a abstração que permite qualquer pensamento. $\mathrm{O}$ objeto tem que dar lugar à representação, e é a alucinação negativa que leva à dissolução do objeto primário, possibilitando que ele migre do centro para o entorno do aparato psíquico, constituindo seus limites. Dessa forma, "a mãe é presa no quadro vazio da alucinação negativa, e torna-se estrutura enquadrante para o próprio sujeito. O sujeito se constrói onde aconteceu a investidura e não o investimento do objeto. Tudo está então no 
lugar para que o corpo da criança possa vir a substituir o mundo externo" (Green, 1983/1988, p. 282). A estrutura enquadrante é a organização narcísica primária, efeito da relação com o objeto materno atravessada pelo trabalho do negativo (De Oliveira et al., 2016). Depois disso, o bebê está pronto para o auto erotismo, ou seja, pronto para ter seu corpo como mundo externo.

Portanto, a alucinação negação é indispensável à constituição do psiquismo, e seus efeitos "desvirtuados" podem ser percebidos em diversas sintomatologias da clínica psicanalítica. A função da estrutura enquadrante, resultado da alucinação negativa e que se caracteriza como "um espaço psíquico pessoal" (Green, 1993/2010), é a de estabelecer o limite do espaço subjetivo. De acordo com Candi (2010), essa estrutura marca a permanência de algo que se constitui próximo da experiência de satisfação, e por isso possibilita a transformação da espera em procura de satisfações substitutas, "transformando a passividade angustiante da espera em investigação, de onde pode advir o sentido" (p.233). Dessa forma, acontece o distanciamento necessário do objeto primário, a partir do qual se dá a simbolização, que possibilita o deslizamento dos significantes, da elaboração e do próprio recalcamento. Portanto, o luto saudável do objeto primário permite que a função objetalizante seja conservada, permitindo a busca de outros objetos substitutos de satisfação. É a partir do estabelecimento da estrutura enquadrante que o princípio de prazer se constitui em uma tendência.

Podemos dizer que Green (1993/2010) abre a possibilidade de se pensar numa negatividade necessária e constitutiva do psiquismo, uma vez que tanto a alucinação negativa quanto a estrutura enquadrante são manifestações do trabalho do negativo e, ao instalarem a "ausência necessária" (De Oliveira \& Winograd, no prelo), criam o espaço pessoal do qual surgirão as produções psíquicas. Portanto, as operações negativizantes que a pulsão de morte promove através da função desobjetalizante não apresentam uma dimensão única e nem necessariamente destrutiva, uma vez que possibilitarão a perda do objeto primário e sua substituição por outros objetos, estabelecendo assim os limites intra e inter psíquicos e os processos de simbolização, criadores de sentido.

Mas, para que isso aconteça, é necessário que a relação com o objeto seja suficientemente boa e permita o seu apagamento. É preciso que a pulsão 
de morte esteja ativa também na mãe, e que esta se deixe apagar. O objeto precisa se ausentar algumas vezes, não se mostrando como absolutamente necessário, o que permite que a criança realize seu apagamento. Este esquecimento possibilita a inscrição do objeto como estrutura psíquica interna, um vazio a partir do qual se darão todos os processos de representação. Segundo Carvalho e Viana (2012), esse vazio que se constitui como uma estrutura "é o que permite as distâncias, ausências e falhas dos objetos sem que isto implique uma ameaça de aniquilamento da estrutura psíquica” (p. 39).

Nos casos em que os objetos realizam sua função estruturante, os mesmos não provocam ruídos, se tornando invisíveis, uma vez que foram apagados na formação da estrutura psíquica. Por outro lado, quanto mais o objeto falha em sua função, mais presente e ruidoso se mostra, tendo em vista que, justamente por seu excesso, não pode ser elaborado e esquecido. O objeto que não se deixa apagar se caracteriza como traumático e, ao invés de constituir o espaço interno, tem como efeito todas as manifestações desestruturantes do trabalho do negativo. 


\section{4 \\ O fracasso do trabalho do negativo e a pulsão de morte como protesto vital}

Como visto no segundo capítulo, a teorização sobre o trabalho do negativo abarca um grande campo de conceitos na psicanálise. Tendo isso em vista, é possível afirmar que esse trabalho pode exercer tanto uma ação estruturante e constitutiva do psiquismo quanto uma ação desestruturante, desorganizadora e, portanto, ameaçadora do mesmo. Quando o aspecto ameaçador se sobrepõe sobre o constitutivo, estamos diante do "negativo do negativo". De acordo com Green (2002/2008), o negativo se apresenta em todo seu peso na patologia, uma vez que o sucesso desse trabalho não provoca ruídos e, dessa forma, não se faz notar. No entanto, se o trabalho do negativo fracassa em sua função de constituir os limites egóicos, é possível ter notícias disso através de seus efeitos patológicos, que podem ser interpretados como efeitos colaterais do fracasso da negativização (De Oliveira \& Winograd, no prelo).

Green (1993/2010) se pergunta: "por qual deriva, por qual processo de desvio o trabalho do negativo se torna aqui trabalho "negativista'?" (p. 109). Essa "deriva do negativo" está totalmente relacionada ao lugar que o objeto ocupa no psiquismo do sujeito. Como visto no capítulo anterior, a relação estabelecida entre o sujeito e o objeto primário é fundamental no momento da constituição psíquica, sendo o objeto extremamente necessário também no caminho para atingir a satisfação pulsional. Toda essa importância implica que esse objeto é também portador de uma potencialidade traumática, o que faz Green (1983/1988, 1993/2010) falar em um "objeto-trauma". Isto se refere à ameaça que o objeto apresenta para o ego, uma vez que sua existência força o ego a se modificar. É a partir dessa potencialidade traumática que articularemos a relação com o objeto ao fracasso do trabalho do negativo. 


\section{1 O objeto absoluto}

O aparato psíquico se vê diante da influência de duas entidades diversas: a pulsão, que pressiona exigindo a satisfação, e o objeto externo. Esse objeto pode ser capaz de realizar a meta pulsional e garantir a satisfação procurada. Além disso, ele desempenha, de acordo com Candi (2010), “o papel de auxiliar do Eu embrionário da criança" (p. 245). Um "eu embrionário" aponta para um ego cujas fronteiras e limites egóicos estão ainda a ser constituídos. E, nessa constituição psíquica, já pudemos observar o papel fundamental desse objeto externo que, nesse momento, é "tanto o psiquismo da mãe como sua maternagem e seu holding, que dá sustentação temporal ao enquadre externo" (Candi, 2010, p. 245).

A partir de A Negativa (Freud, 1925/2006), pudemos constatar a importância não só do objeto, mas também da pulsão de morte na delimitação das fronteiras egóicas. No momento primário de diferenciação do mundo interno e do mundo externo, a pulsão de morte é responsável pela excorporação que atribui ao não-eu os conteúdos indesejáveis. Mas, para que o princípio de realidade seja instaurado no psiquismo, o objeto precisa falhar em atender todas as demandas da criança, o que possibilita que ela busque artifícios próprios para lidar com a frustração proporcionada por essa falha.

A realização alucinatória do desejo é um dos primeiros recursos utilizados pelo psiquismo nesse momento, no qual o objeto alucinado é constituído pela projeção de características relacionadas ao prazer e ao bemestar. Green (1993/2010) afirma que esse objeto alucinado é mais fruto de uma idealização do sujeito do que resultado de lembranças de uma experiência real. No encontro com a realidade, é grande a possibilidade de que o objeto não corresponda a todas essas características positivas, o que provoca a frustração. Os afetos violentos que daí derivam são evacuados pela criança, que toma o objeto como causador de seu mal-estar.

No entanto, se a experiência com o objeto real não for inteiramente negativa, reafirmando na relação alguns traços de prazer, o sujeito sustentará o desejo de conservar o objeto e poderá lidar com a frustração da situação a partir da operação do recalque. Dessa forma, a relação com o objeto pode 
proporcionar ao sujeito "o sentimento do valor de sua existência" (Green, 1993/2010), o que faz com que o mesmo se reconheça como desejante. Numa relação com essas condições, Green (1993/2010) afirma que “o Outro pode existir em estado separado e cobrar certas renúncias em contrapartida ao amor proporcionado" (p.110).

Esse contexto é condizente com um objeto que cumpre suas funções suficientemente bem. Isto significa que o objeto pôde estimular e conter a pulsionalidade, assim como conseguiu permitir e suportar o distanciamento necessário para seu apagamento. Como consequência, através de sua alucinação negativa, foi possível a constituição da estrutura enquadrante, espaço a partir do qual surgem as representações e os processos de simbolização e do pensamento, bem como a emergência do desejo e a busca de outros objetos substitutos de satisfação. Contudo, em certos pacientes, como os que caracterizam os casos limite, o objeto primário falha em realizar tais funções tão importantes e é nessas situações que podemos observar toda a sua potencialidade traumática, uma vez que suas respostas ultrapassam as capacidades psíquicas da criança de elaboração.

Mas o que significa isso? Como visto anteriormente, o objeto primário precisa ser perdido para que a separação aconteça e promova a construção de um espaço psíquico pessoal (Green, 1983/1988, 1993/2010). Se a mãe se apresenta como objeto absoluto que não pode ser perdido e nem apagado, a criança terá dificuldades em exercer a negatividade positiva que permitirá o seu apagamento. Se o objeto não se deixa esquecer, não permitindo sua negativação pelos movimentos pulsionais e nem podendo conter tais movimentos, ele permanece sempre excessivamente presente, não sendo introjetado como estrutura e ocupando o espaço psíquico que deveria estar vazio. O "objeto absolutamente necessário" acaba por se transformar em objeto absoluto quando se apresenta de forma excessiva. Sobre um objeto excessivamente presente, Figueiredo e Cintra (2004) afirmam que

uma mãe 'superprotetora' é sempre excessivamente sedutora e traumatizante, não importa quais sejam suas intenções, pois é incapaz de exercer efetivamente uma função de continência, antitraumática. Por outro lado, com um objeto assim ameaçador e do qual o indivíduo deve se proteger, a função estimulante também não pode ser internalizada, pois seria excessivamente perturbadora (p.21) 
Da mesma forma, um objeto excessivamente distante e indisponível também não cumpre suas funções suficientemente bem, uma vez que sua ausência é sentida como excesso, do mesmo modo que a presença excessiva da mãe superprotetora. Isto significa que, em ambos os casos, o excesso configura o objeto como traumático.

É por isso que Green (1983/1988) fala de uma coalescência entre o objeto e a pulsão, situação na qual, ao invés de conter a pulsão e torná-la tolerável, o objeto como que a intensifica, a tornando inassimilável. Dessa forma, "a distância entre a 'alteridade' pulsional e a alteridade subjetiva não pode evitar a rejeição, o nó das duas formas de alteridade torna-se inextricável" (Green, 1993/2010, p.110). Isso significa que a pulsão e o objeto se identificam de tal forma que as exigências pulsionais não podem ser satisfeitas por ele. $O$ objeto primário, que quase não se constitui como um objeto, é agora radicalmente pulsional. É como se acontecesse uma "transferência da fonte pulsional ao objeto" (Green, 1993/2010), como se este não fosse um objeto investido pela pulsão, mas se configurasse como a própria pulsão.

Dentro deste quadro, é difícil acontecer uma mediação simbólica na relação com o objeto, que se torna então insuportável. Este objeto não consegue conter a potência da força pulsional, tampouco ajudar o indivíduo em sua significação e representação. Como consequência disso, o trabalho do negativo fracassa em sua função de negativização do objeto materno, que permanece, assim, sempre demais (Green, 1983/1988). Portanto, o sujeito vive a impossibilidade de perder esse objeto primário, não conseguindo evacuá-lo para que este seja esquecido. Uma vez que o objeto não pode ser elaborado, tampouco pode ser substituído por novos objetos, não possibilitando, dessa forma, a renovação do arsenal representativo (Candi, 2010, p. 200). Segundo Figueiredo e Cintra (2004), "estes pacientes nem podem reter e fazer seu, sem expulsar e tornar alheio, nem podem se apropriar de seus objetos, nem podem diferenciar-se deles. Amam, odeiam, temem e dependem com a mesma intensidade e simultaneamente" (p. 36).

O não apagamento do objeto primordial caracteriza o fracasso do processo de separação individualizante entre mãe e bebê. Isso resulta numa luta para reter o objeto primário, o que tem como resultado que o sujeito reviva repetidamente a perda desse objeto, agora confundido com si próprio. Portanto, 
essa perda que se repete é sempre uma perda narcisista (Green, 1983/1988), o que se traduz no sentimento de vazio radical e leva o indivíduo a um universo mortífero. Preso entre a dependência do objeto primário e uma tentativa excessiva de libertar-se dele, o sujeito vive uma dupla angústia: tanto de ser invadido pelo objeto, quanto de perdê-lo. Essa angústia representa a impossibilidade de aceitar um novo objeto, que não o primário: “o objeto primário pode até ficar como que entalado: a criança nem está dele acompanhada nem pode largá-lo" (Carvalho \& Viana, 2012, p. 41).

Isso significa que o sujeito luta para manter a relação de amor com o objeto primordial, que continua a ocupar o espaço psíquico que deveria estar vazio. Podemos afirmar, portanto, que a dificuldade de separação se apresenta como questão central nesses casos. O indivíduo se fixa assim de maneira ambivalente, através do amor e do ódio a esse objeto, agora absoluto. A dupla angústia expressa, por um lado, o excesso da onipresença do objeto, por outro, a falta e inacessibilidade do mesmo no psiquismo, o que impossibilita que a ausência seja representada, e tem graves consequências para os processos de simbolização e pensamento.

Portanto, o que aparece como questão é que o registro da dimensão da ausência não pode se dar. Tanto um objeto sempre presente, que nunca se ausenta, quanto um objeto sempre distante, que nunca está presente, são incapazes de instaurar a noção de ausência como presença em potencial que, como já vimos, é tão necessária para que o sujeito consiga ter a segurança e confiança que possibilitam a perda do objeto primário. Aqui, o objeto primário se caracteriza como absoluto justamente pela impossibilidade da criança de perdê-lo. Dessa forma, não é um espaço psíquico pessoal disponível que se constrói no psiquismo, mas um espaço que se esforça por manter a imagem da mãe (Green, 1983/1988).

É como se a busca fosse por nunca ter que encarar a ausência que é parte de qualquer relação amorosa, inclusive a transferência com o analista. Já pudemos ver como é a capacidade de tolerar e suportar a ausência do objeto primário que possibilita a sua representação e substituição. Essa tolerância possibilita o desenvolvimento da própria atividade de representar, não de apenas representar o objeto primário, mas de representar o que quer que seja. 
Num momento posterior, a ligação dessas representações constitui o pensamento. Assim, é a partir de sua ausência que o objeto pode ser pensado.

Mas, como afirma Candi (2010), aqui estamos diante de casos nos quais essa primeira manifestação do negativo, qual seja, a ausência, não pôde construir o mundo representacional a partir da confiança na relação com o objeto. Por isso, o trabalho de representação fica "cativo de seus derivados pulsionais. A reapresentação não surge como substituto suficientemente bom para se desprender do objeto externo absolutamente necessário" (Candi, 2010, p. 255).

É em decorrência disso que Green (1983/1988) afirma ser abusivo falar em nostalgia ou desejo com tais pacientes. De acordo com o autor, o movimento desejante descentra o sujeito de si mesmo, uma vez que a busca pelo objeto da falta, faz o sujeito sentir que seu centro está nesse objeto do qual está separado. Portanto, o desejo é o que promove a consciência dessa separação e da "dissincronia temporal com o objeto, criadas pela postergação necessária à experiência de satisfação" (Green, 1983/1988, p. 21). Ora, se pensamos o desejo como a busca de reavivar a representação de um objeto perdido, e se nesses casos não há perda desse objeto primário e tampouco sua representação e multiplicação em novos objetos, como podemos falar de desejo?

O movimento desejante consiste em refazer os passos de uma experiência anterior de prazer na falta do objeto que a propiciou. Podemos dizer que esse movimento é uma repetição norteada pelo princípio de prazer, no qual a negatividade exerce seu papel constituinte e sua função objetalizante, ao gerar objetos de desejo ou de repulsa. Segundo Figueiredo e Cintra 2004,
desejo requer (1) o distanciamento e a multiplicação dos objetos (uma negação 'para fora'), a partir de (2) um esquecimento do objeto introjetado na forma de um vazio estruturante, e (3) em decorrência, a tolerância à diferença entre o psiquismo e os objetos de atração ou repulsão. Esta tolerância só é alcançada quando há um psiquismo suficientemente organizado em torno do vazio estruturante possibilitado pelo 'objeto absolutamente necessário' que se deixou esquecer, transformando-se, ele mesmo, em parte do aparelho mental (p. 21)

Quando o objeto não é bem sucedido em sua função de estimular e conter a pulsionalidade, e de se deixar apagar, o que possibilita sua negativação para fora, provocando sua multiplicação em objetos substitutos, e sua 
negativação para dentro, que constrói o espaço vazio, permanece ocupando o espaço psíquico do sujeito. É um objeto que “nem está suficientemente disponível como 'esquecido' - estrutura enquadrante - nem suficientemente distanciado e multiplicado como objeto de atração e repulsão" (Figueiredo \& Cintra, 2004, p. 22). Dessa forma, podemos observar que a não separação mãe/bebê acarreta em falhas tanto na delimitação do espaço psíquico, quanto nas capacidades de representar, pensar e desejar novos objetos.

Devido à impossibilidade de canalizar a pulsionalidade pelas vias do desejo, o sujeito fica submetido a uma extrema violência pulsional, o que fará com que lance mão de defesas primárias, como veremos adiante. Não podendo dispor dos recursos psíquicos da fantasia propiciados exatamente pela estrutura do desejo, que dariam a esperança de reencontrar o objeto perdido, a experiência de satisfação se transforma numa experiência de dor. $\mathrm{O}$ sujeito fica como que destinado a repetir a frustração relativa ao objeto, incapaz de encontrar a satisfação. É por isso que, nesses casos, a análise deve atuar mais na realização do trabalho de luto do objeto do que na resolução dos conflitos edípicos que, mesmo que estejam presentes, não são a questão central aqui.

O estabelecimento da estrutura enquadrante e a delimitação do duplo limite, que estruturam o psiquismo e possibilitam suas produções criativas, são efeitos do trabalho do negativo estruturante promovido pela pulsão de morte. No entanto, aqui estamos diante de casos em que o trabalho do negativo fracassa e assume, assim, toda sua potência de desorganização. Através da sintomatologia dos casos limite, subjetividades que se organizam em torno de defesas ao traumático, podemos observar toda a desestruturação que a ação da pulsão de morte pode provocar.

\section{2 \\ Clivagem radical e a instabilidade do duplo limite}

Gondar (2014) chama atenção para o fato de que os pacientes que sofrem dos chamados "sofrimentos narcísicos" não são uma única entidade psicopatológica. De forma geral, refere-se a esses pacientes como tendo uma constituição egóica frágil devido a uma vivência traumática com o objeto primário. A fragilidade narcísica apresentada por tais pacientes pode ser 
facilmente reatualizada, uma vez que a assimilação do objeto materno e a integração do eu não foram totalmente estabelecidas. Daí, o narcisismo e as fronteiras psíquicas de tais sujeitos se constituem de forma não muito robusta, podendo se desequilibrar de forma fácil.

Isto seria diferente, por exemplo, das neuroses traumáticas, caracterizadas por "uma fragilização subjetiva circunscrita por um golpe posterior que incide sobre o psiquismo constituído" (De Oliveira \& Winograd, no prelo). Na realidade, aqui é como se o modelo econômico da neurose traumática fosse recuado até o momento da constituição do psiquismo. Nos casos limite, o trauma num momento precoce define uma maneira específica de constituição subjetiva. Esses casos apresentam, portanto, "modos de ser e de sofrer que se caracterizam por uma ausência de coesão subjetiva" (Gondar, 2014, p. 119). Como veremos adiante, tais indivíduos encontram dificuldades para manter o duplo limite.

Portanto, em função do traumático experienciado na relação com o objeto primário, podemos dizer que tais indivíduos se constituíram e se organizaram subjetivamente ao se defenderem desse excesso. Ou seja, nesses casos, o recalque não se apresenta como o principal operador psíquico da subjetividade. Isto não quer dizer que tais indivíduos não recalquem, mas que este não é o mecanismo organizador de seus psiquismos, como é no caso das neuroses. Sendo uma forma primitiva de defesa, a clivagem aparece como o principal modo de subjetivação desses sujeitos. De acordo com Gondar (2014), "a clivagem não incide sobre representações inconciliáveis com o eu, como o recalque; ela age no plano do eu, conduzindo a sua fragmentação e até mesmo à pulverização do eu" (p. 120).

Freud (1923/2006) nos diz que o ego é, sobretudo, um ego corporal formado pelas sensações da superfície do corpo. Mas, além disso, o ego é também a projeção mental da superfície corporal. Em $O$ Ego e o Id (Freud, 1923/2006), vemos que ao ego são atribuídas as funções de unidade, coesão e de síntese dos conteúdos psíquicos. Isto seria o caso de um ego cujas fronteiras psíquicas estão bem delimitadas e no qual o recalque pode operar como mecanismo organizador. No entanto, quando o psiquismo precisa se utilizar de muitas clivagens para se defender de um sofrimento insuportável, o ego pode não ser constituído exatamente dessa forma, uma vez que não é capaz de 
fornecer um contorno próprio ao indivíduo. A fragmentação sobrevém então às tentativas de unidade e integração que geralmente lhe são atribuídas. Gondar (2014) aponta para a dificuldade que tais sujeitos apresentam de passar de um registro onde as pulsões são parciais e dispersas para a unidade proporcionada pelo narcisismo.

De acordo com Cardoso (2010), tais situações clínicas devem ser consideradas como limite por este ser exatamente o núcleo central da problemática que apresentam estes sujeitos enquanto marcados pela insistência do traumático que ameaça seus limites psíquicos fragilmente constituídos. Como vimos no capítulo anterior, na teorização de Green (1900, 1982/2003) o duplo limite promove a divisão de territórios separados, mas que se comunicam e realizam trocas entre si. Nos casos limite, parece haver um problema exatamente no estabelecimento do duplo limite, o que significa que tais pacientes apresentam dificuldades na diferenciação eu/outro e de delimitar os territórios que constituem o aparato psíquico.

Em consequência disso, o diálogo entre interno e externo fica prejudicado, bem como a comunicação e a troca entre os espaços do psiquismo, que possuem cada um sua função. Portanto, uma vez que as diferenciações não se estabelecem de forma sólida, há uma dificuldade de estabelecer relações de correspondência entre o espaço interno e o espaço externo, correspondência necessária para a possibilidade de comunicação entre ambos e para a circulação do sentido (Candi, 2010).

Segundo Candi (2010), na constituição psíquica dos casos limite, "as cadeias de transformação interna e externa não puderam se estruturar ou permaneceram muito curtas, o que limita as vias secundárias de elaboração da satisfação pulsional e a sua comunicação no nível externo" (p. 224). Isto tem como consequência que a pulsionalidade não pode ser bem elaborada e nem integrada ao ego, o que a torna traumática e desorganizadora, provocando núcleos fragmentados dentro do psiquismo. Esses núcleos fragmentados, produtos do mecanismo da clivagem, formam um tecido psíquico interno como que esburacado.

A clivagem é um mecanismo importante na constituição egóica mesmo de um indivíduo neurótico. O psiquismo produz cisões dentro de si mesmo, na tentativa de separar o bom e o mau, num movimento disjuntivo que é efeito da 
ação da pulsão de morte. Portanto, tais clivagens são, na realidade, essenciais para a constituição do aparato psíquico, uma vez que o aliviam de um excesso de tensão, que nesse momento primitivo pode paralisar todo o aparato. Podemos pensar que as clivagens produzem um alívio que preserva, portanto, o trabalho psíquico. Esse mecanismo é "fundamental para sustentar a importância do limite no desenvolvimento psíquico, pois é ele quem produz uma primeira divisão necessária para a estruturação do psiquismo" (Candi, 2010, p. 247).

No entanto, na constituição subjetiva dos casos limite, o mecanismo da clivagem acontece de forma intensificada, trazendo consigo uma radicalidade extrema que impede o trabalho de representação e paralisa o aparato. Quando os limites psíquicos não se constituem, não possibilitando a contenção e elaboração da pulsionalidade, predominam no aparato psíquico cisões das mais diversas, cindindo realidade interna e externa, afeto e representação e mesmo as instâncias psíquicas. De acordo com Candi (2010), essas clivagens “impedem que os espaços psíquicos se organizem numa estrutura complexa e deixam o aparelho psíquico num estado amorfo de fusão e confusão que impossibilita a discriminação (por meio do principio prazer/desprazer) dos afetos internos e da realidade externa”. (p.239)

Quando o mecanismo da clivagem, a princípio fundamental para o estabelecimento das fronteiras psíquicas, ocorre de maneira radical e excessiva, não pode estruturar limites internos flexíveis e necessários que possibilitam os processos de transformação da energia pulsional e a simbolização. Não pode acontecer, dessa forma, a mediação simbólica necessária entre a realidade interna e a realidade externa, o que dificulta a emergência da atividade representacional e a própria capacidade de pensar. As clivagens radicais têm como efeito a preponderância da pulsão de morte, de forma que a função desobjetalizante se sobrepõe à função objetalizante, o que tem como consequência prejuízos na simbolização e na própria capacidade de desejar, como já vimos.

Dessa forma, é a radicalidade extrema do mecanismo da clivagem que impede a construção de um espaço interno pessoal, construção que está intimamente relacionada ao objeto primário ser capaz de cumprir suas funções suficientemente bem. O sujeito só consegue realizar a ligação da pulsão e de 
seus excessos a partir de uma boa relação com o objeto materno que investe significativamente nele. No entanto, quando o objeto primário não serve de apoio para a estruturação do psiquismo da criança, passa a ser mais uma fonte de conflito. Portanto, além de se ver diante do conflito com sua própria pulsionalidade, esse ego em constituição terá que lutar também contra o objeto, que de objeto-trauma passa a se configurar como objeto-louco, tanto enlouquecido quanto enlouquecedor (Green, 1983/1988). A luta contra o objeto externo é o que resulta na radicalização da clivagem que, por sua vez, isola os espaços psíquicos (Candi, 2010).

A instabilidade do duplo limite resulta numa instabilidade temporal. O primeiro dos limites, que se refere à diferenciação dentro/fora, passa a funcionar a partir da lógica pulsional, se caracterizando então por uma temporalidade evacuativa que é baseada no imperativo das satisfações pulsionais, urgentes de serem saciadas. Por sua vez, o segundo limite, que divide as instâncias psíquicas dentro do aparato, passa a funcionar a partir da lógica dos processos primários e da temporalidade do inconsciente, ou seja, pela atemporalidade. Sem fronteiras adequadamente estabelecidas, o psiquismo se estrutura de forma caótica. Quando o psiquismo não tem sua contenção a partir de um limite horizontal, o do recalque, passa a operar a partir do limite vertical, o intersubjetivo. Ocorre então uma "substituição do limite interno intrapsíquico pelo limite externo intersubjetivo" (Candi, 2010, p. 258), o que faz com que os conflitos psíquicos, típicos de pacientes neuróticos, não apareçam tanto na clínica dos pacientes-limite.

Ameaçado pela desorganização proporcionada por suas fronteiras instáveis, a função mais importante desse ego fragilizado, cuja sintomatologia se situa na borda da psicose, parece ser a de manter sua unidade egóica. Garcia (2010b) nos diz que, nesses casos, "a manutenção dos limites psíquicos é ainda mais importante do que a satisfação pulsional e o investimento narcísico, sugerindo que o movimento desejante ocupa lugar secundário em relação à necessidade de se defender do objeto intrusivo" (p. 97). Como vimos acima, o sujeito que se constitui a partir de uma relação excessiva e traumática com o objeto primário, tem seu espaço psíquico ainda ocupado e não pode, portanto, desejar. 
Nesses casos, o trabalho do negativo tem então como função o que não pôde ser realizado no momento da constituição psíquica: a discriminação entre passado e futuro, o que permitiria a continuidade do tempo; diferenciação entre bom e ruim; constituição do contorno egóico, estabelecendo a distinção dentro/fora; elaboração da pulsionalidade desligada, o que permitiria que ela fosse simbolizada e pensada através de imagens e pensamento (Candi, 2010).

Ou seja, o trabalho do negativo opera aqui na tentativa de estabelecer os limites egóicos que não foram bem constituídos num momento precoce (De Oliveira \& Winograd, no prelo). O enquadre analítico deve proporcionar as condições necessárias para que aconteça o trabalho da simbolização, através da formação do tecido representacional que possibilita a formação de sentido. No que se refere ao mecanismo de clivagem, podemos apontar que, na constituição subjetiva dos casos limite, este se caracteriza como uma forma de defesa frente a um objeto primário cujas respostas à criança foram inadequadas. $\mathrm{O}$ psiquismo ameaçado pelo traumático acaba por se organizar em torno dessa forma defensiva primitiva, o que tem como consequência ainda a compulsão à repetição e o desinvestimento.

\section{3 \\ Compulsão à repetição e desinvestimento}

Já apontamos que, quando falamos em casos limite, estamos nos referindo a sujeitos que apresentam uma fragilidade narcísica e que se utilizam de defesas primárias para lidar com as angústias insuportáveis advindas da relação com o objeto materno, ou seja, indivíduos que apresentam dificuldades em dominar a violência pulsional a que estão expostos. No geral, a relação com o outro é grande dificuldade para esses pacientes. Assim, além da radicalização da clivagem, podemos observar, nesses casos, duas outras formas de se defender do traumático: a compulsão à repetição, como vimos no primeiro capítulo, e o desinvestimento (Green, 1983/1988, 1993/2010). A radicalização da função desobjetalizante pode resultar no ataque ao investimento primário de objeto, qual seja, o desinvestimento, como veremos adiante.

Portanto, a violência interna experienciada por tais pacientes provoca respostas de evacuação igualmente violentas, como as apresentadas nas compulsões. Assim, em suas sintomatologias, tais sujeitos convocam o ato e o 
corpo. Ao invés da simbolização, as respostas produzidas são extrarepresentativas. Dessa forma, o imediatismo da compulsão à repetição é resultado da precariedade dos processos representativos dos sujeitos, os quais são necessários para que a elaboração aconteça e uma nova resposta ao excesso pulsional possa ser produzida. Portanto, esses sujeitos se encontram passivos diante da irrupção do pulsional que não conseguem metabolizar psiquicamente (Cardoso, 2010).

Dessa forma, repetir é a tentativa de recuperar a capacidade de tais sujeitos de estabelecer ligações, capacidade que se encontra em pane devido ao funcionamento em traumático que apresentam. A pulsão de morte é chamada devido à necessidade de inscrição e processamento de impressões que "permaneceram irrepresentadas e ligadas a uma pulsionalidade sem contorno" (De Oliveira \& Winograd, no prelo, p. 22). O processo de exteriorização, em detrimento da interiorização, que supõe uma elaboração, é característica do modo de funcionamento desses quadros, que recorrem à expulsão da experiência psíquica insuportável (Cardoso, 2010). Esse esvaziamento psíquico implica num desconhecimento do sujeito em relação à sua própria realidade psíquica, uma vez que a busca é por se desfazer do excesso irrepresentado.

Nesses casos, há um desintricamento das pulsões de vida e de morte, e é como resultado desta desintrincação que a pulsão de morte é intensificada e passa a produzir desintegrações, não mais diferenciações (De Oliveira et. al. 2016). A função desobjetalizante, própria desta pulsão, domina o cenário psíquico. A partir disso, as manifestações do negativo se apresentam não mais como estruturantes, mas agora patológicas e destrutivas. Green (1990) nos diz que "quanto mais o trabalho do negativo se aproxima do representante psíquico da pulsão, mais a vida está em perigo" (p. 81). Os desdobramentos psíquicos patológicos podem incluir desde a apatia até a depressão, e as adicções funcionam como um recurso muito utilizado para lidar com essa intensa angústia, uma vez que o funcionamento psíquico passa a ser processado através do transbordamento pulsional.

Ameaçado por esse transbordamento, a luta do sujeito é, como já dissemos, apenas uma luta "territorial", uma busca de manter sua autonomia e integridade egóica. Portanto, não é a busca pelo prazer que orienta esse psiquismo. Não mais orientado pelo princípio de prazer, o aparato psíquico 
busca a sobrevivência, que muitas vezes só pode ser realizada através do recolhimento narcísico. Entra em jogo a lógica pulsional do desinvestimento, manifestação do narcisismo negativo, na busca por reduzir as tensões do psiquismo até o nível zero, última medida defensiva frente ao objeto excessivo e contra a pulsionalidade que não foi contida na relação com o mesmo. Frente ao objeto louco, o sujeito procura neutralizá-lo para se defender (Green, 1983/1988).

Com o conceito de narcisismo negativo, Green (1983/1988) coloca a pulsão de morte e a destrutividade no centro dos sofrimentos narcísicos. Ao atacar os vínculos através do desinvestimento radical, o narcisismo negativo busca chegar a um estado de vazio. O desengajamento é aqui a marca da relação com o objeto primário, relação essa que produziu uma ferida sem cicatrização. Inclusive, Green (1993/2010) afirma que, nesses casos, toda relação com o objeto busca promover a insatisfação e que "o negativo é tão expandido quanto seria em um país onde a experiência de satisfação não existisse" (p. 111). Tal desengajamento é bem diferente do deslocamento, que pressupõe outra ligação, o que enriquece a cadeia de representações a partir de novas associações. No caso do desengajamento, a ligação que possibilita a construção de sentido é desfeita (Green, 1993/2010).

Como consequência, o obstáculo narcísico parece ser a maior resistência à análise. Esse campo clínico é dominado pelas angústias catastróficas, sentimentos de vazio e de morte psíquica, expressões da busca do narcisismo negativo em alcançar um estado de "não ser" através da desobjetalização radical. Isto significa que a destrutividade é dirigida não ao objeto, mas ao próprio eu. Dessa forma, o sujeito busca uma maneira de terminar com seu sofrimento, uma vez que sua existência e esse sofrimento coincidem (Green, 1983/1988, 2000). Na palavras de Green (2002/2008), “o processo de autodesaparecimento se põe em movimento, representando ao mesmo tempo a última escapada frente a uma situação contraditória e traumática" (p. 275).

Este movimento se caracteriza como o extremo das possibilidades psíquicas do aparato psíquico, uma vez que "a psique vê-se capitulada pela pulsão de morte, silenciando numa forte tendência a inércia simbólica, o que contraria todos os valores da vida" (Garcia \& Damous, 2009, p. 113). Em casos 
clínicos como a melancolia, o autismo e a anorexia mental, podemos observar a prevalência da função desobjetalizante. $\mathrm{O}$ investimento objetal é, portanto, intensamente atacado, recurso defensivo último contra o caos pulsional. No limite, é o desinvestimento do próprio processo de investimento. Segundo Carvalho e Viana (2012),

A função desobjetalizante ataca os próprios investimentos, o que
significa um ataque às funções objetalizantes que possibilitam a
constituição do psiquismo, do pensamento e dos processos de
simbolizção. Lançado à "morte psíquica" o sujeito limite vive as
sensações de abismo e de aniquilamento. Aspirar a um nível zero de
excitação pulsional pode ser o caminho para que ele se livre das
angústias catastróficas. O nível zero de excitação pulsional é o que se
pode chamar de trabalho negativo das pulsões de destruição em sua
expressão máxima (p. 51)

Green (1993/2010) destaca alguns pontos que têm importância na constituição subjetiva dos pacientes-limite. O primeiro fator é a grande diferença entre a realização alucinatória de desejo e a real experiência de satisfação na relação com o objeto. A partir dessa diferença, o sujeito passa a enxergar o objeto como "não desejante do desejo do sujeito" (Green, 1993/2010, p. 111). Isto resulta numa busca de satisfação mais referida a contentar o objeto do que o próprio sujeito, que supostamente é o sujeito desejante. No entanto, como o objeto é que deveria satisfazer o sujeito, este se sente como que "despossuído" de sua própria satisfação. Nesta situação, o sujeito se extingue, abandonando a posição de agente do próprio desejo e se transformando em objeto do objeto. O paradoxo aqui é que esse objeto constitui como que um com o sujeito. Dessa, forma, nenhum dos dois se constitui individualmente pela separação, o que "alimenta a crença de que o objeto é uma parte do Eu e, portanto, não tem existência autônoma. Essa crença está a serviço da onipotência" (Green, 1993/2010, p. 124).

Como consequência disso, o objeto se constitui como uma instância persecutória dentro do sujeito, que, por sua vez, só consegue construir do outro e de si mesmo representações sem muito volume ou consistência. Portanto, todos os esforços do sujeito são na tentativa de escapar desse domínio e da pulsionalidade do objeto, este sempre imprevisível e ameaçador. É na constante tentativa de fuga do objeto que o sujeito adota um "desejo de não desejo", com o objetivo de se tornar independente de qualquer objeto, sem necessidade ou desejo. Ou seja, ao sufocar seus próprios desejos e perspectivas de 
desenvolvimento psíquico, espera conseguir também sufocar o objeto invasivo. Para isso, se retira cada vez mais em si mesmo, retraindo os próprios investimentos. Nas palavras de Green (1993/2010),

Em qualquer caso, o Outro é sempre a instância de uma autoridade mortífera que não quer a vida, o desenvolvimento nem as capacidades criadoras, mas a permanência de uma relação parasitária fria e cristalizada. O negativo aqui retomou todos os seus atributos de potencialidade, de virtualidade, mas para fixá-los para sempre como imobilismo psíquico com negação do tempo que passa (p.112).

Essa forma do negativo é consequência da relação traumática com o objeto primário, e se caracteriza como uma derivação da negatividade criadora de que falamos no segundo capítulo. Mas, como vimos acima, estamos nos referindo a sujeitos que se veem diante de uma dupla angústia: tanto a de invasão pelo objeto ameaçador quanto o medo de perder esse objeto absoluto. Portanto, se por um lado sua procura é por conseguir realizar a separação desse objeto e individualizar-se, mantendo assim sua unidade egóica, por outro observamos a grande dificuldade de separação do mesmo. É por isso que Green (1993/2010) afirma que, por mais que a autonomia seja buscada, ela é também odiada, uma vez que indica que o objeto é independente. Dessa forma, a dor mantém a presença do objeto sempre constante, impedindo qualquer possibilidade de diferenciação, separação e subjetivação.

Portanto, o que podemos observar é que o vínculo com o objeto não é realmente rompido, mas, ao contrário, fortemente investido e mantido à custa do próprio sujeito. A constância do vínculo com o objeto primário parece ser o que garante a sobrevivência de tais pacientes. Tal objeto é responsabilizado por todo o sofrimento, mas, paradoxalmente, impossível de ser abandonado. O sofrimento do sujeito aponta então para uma doação de amor e para um vínculo extremo com o objeto, mesmo que intrincado com "o ódio mais pertinaz, mistura da vida à morte" (Green, 1993/2010, p. 114). Dentro desse contexto, o trabalho do negativo, agora em seu aspecto desestruturante, se apresenta sob uma dupla potencialidade:

(...) de um lado, uma pulsionalidade não assimilável, porque suas refrações através dos sistemas da representação e o papel mediador delas em face da realidade não foram objeto de um reconhecimento devido à ausência de apropriação pelo $\mathrm{Eu}$ - com o ônus para ele de se defender, se for o caso. De outro lado, um Eu que ficou marcado de forma indelével pela ferida que lhe causou a consciência de uma vida independente do objeto - portanto dos vínculos deste último com 
outros objetos (o outro do objeto). Esse mesmo Eu está destinado à solidão e ao desamparo tanto mais que ele próprio não conseguiu encontrar satisfação na aquisição de sua própria autonomia. Para concluir, ele se constituiu em bastião vivo sob a regra da inibição das relações de alteridade (...) (Green, 1993/2010, p. 169).

A aleatoriedade do objeto pode provocar, dessa forma, desequilíbrios que provocam movimentos pulsionais "anárquicos e defensivos" (Green, 1993/2010), o que tem como resultado um nível extremo de desinvestimento. O desengajamento subjetal que é desencadeado a partir daí pode chegar ao limite do sentimento de existência, abalando a ancoragem corporal do sujeito e causando sensações de fragmentação. Isto aponta para um rasgo do tecido psíquico, uma vez que tais sintomas não são simbolizados, podendo surgir angústias insuportáveis e o sentimento de desaparecimento do ego.

De acordo com Green (1993/2010), nesses casos “o próprio Eu é arrancado do mundo interior - pela onipotência conferida ao objeto que o arrasta em sua desaparição. O negativo atingiu seu limite" (p. 170). Numa tentativa radical de se defender da dupla angústia desorganizadora provocada pela relação com o objeto absoluto, o indivíduo investe, como último recurso, a onipotência do negativo (Green, 1993/2010). Podemos afirmar, portanto, que as manifestações patológicas apresentadas pelos casos limites são tentativas últimas e radicas de dar conta do excesso pulsional que não pôde ser gerido, e que por isso se torna traumático e ameaçador de aniquilar o ego fragilmente constituído.

\section{4 \\ Protesto vital}

Se o caráter destrutivo da sintomatologia apresentada pelos casos limite está dado, sendo facilmente observável e não podendo ser negado ou ignorado, nos interessa, no entanto, pensar para além da destrutividade desses mecanismos defensivos, encarando-os como uma tentativa última de subjetivação e estabelecimento dos limites psíquicos. De Oliveira et al. (2016) afirmam que podemos compreender tais efeitos patológicos como efeitos colaterais da tentativa de elaboração do traumático. Em relação à compulsão à repetição tão frequentemente observada por tais sujeitos, esta pode também ser compreendida como um esforço de estruturação psíquica, uma vez que busca a 
ligação da pulsionalidade excessiva. Isto significa que o domínio das excitações que a compulsão à repetição busca atingir pode também ser pensado como um indício de trabalho psíquico (De Oliveira et al., 2016).

A partir desse mecanismo compulsivo, nos deparamos, portanto, com um constante esforço do psiquismo de significar e assim elaborar os conteúdos traumáticos. Como vimos no primeiro capítulo, tal mecanismo busca possibilitar a retomada do princípio de prazer como tendência do funcionamento do aparato psíquico. Além disso, há um aparente paradoxo nessa repetição do mesmo: se, por um lado, esta repetição falha na tentativa de elaboração do excesso pulsional, por outro, é bem sucedida ao evacuar do psiquismo uma intensidade insuportável (De Oliveira \& Winograd, no prelo). Este outro modo de trabalho psíquico, a saber, a detonação da descarga, é também trabalho da pulsão de morte. Não sendo possível significar o excesso que ameaça a unidade egóica, o psiquismo se desfaz momentaneamente do mesmo. Extinguindo a intensidade que ameaça a integridade egóica, o aparato psíquico busca reunir forças para reestabelecer o seu funcionamento normal. Deste modo, o objetivo é encontrar uma saída frente ao traumático que aproxima do desamparo.

Os mecanismos patológicos resultantes do fracasso do trabalho de negativação e que têm como motor a pulsão de morte, podem ser pensados, portanto, como efeitos colaterais da tentativa última e radical de sobrevivência e resistência de um aparato que se esforça pela subjetivação. De acordo com De Oliveira \& Winograd (no prelo), “esta descarga exigida pela pulsão de morte, embora impeça a elaboração, livra momentaneamente o psiquismo do excesso, podendo, mais profundamente, ser entendida como uma tentativa sempre renovada de constituição posterior da estrutura enquadrante" (p. 23). Isto aponta para o esforço de realizar o trabalho do negativo estruturante e estabelecer os limites psíquicos que não puderam ser fortemente consolidados no momento da constituição psíquica. Na realidade, a simples sobrevivência do sujeito frente ao traumático desestruturante já aponta para a sua insistência na vida (De Oliveira et al., 2016).

Dessa forma, pensar a pulsão de morte somente como retorno ao inorgânico ou como uma pulsão de destrutividade não nos parece abranger a total complexidade do conceito. Não se trata, portanto, de uma compreensão 
niilista dos processos destrutivos. Inclusive, pensar as manifestações patológicas como formas de sobrevivência psíquica e tentativa de subjetivação acarreta em modificações importantes para a clínica dos pacientes que apresentam tal sintomatologia: é a diferença entre enxergá-los como autodestrutivos sem muita saída ou apostar numa tentativa de trabalho.

A partir disso, estamos de acordo com Zaltzman (1994) quando afirma que a pulsão de morte está a favor da vida, sendo o protesto mais radical na tentativa de preservá-la. Em seu livro A pulsão anarquista (1994), a autora apresenta uma visão inovadora do conceito de pulsão de morte, na qual apostamos, e comenta o caso de uma paciente sua, cuja relação com o filho era simbiótica. Mesmo que a mulher tivesse outros filhos, esse menino ocupava lugar especial em seu investimento materno, e mãe e filho "alimentavam um pelo outro um amor incondicional, atribuindo-se reciprocamente uma onipotência benéfica absoluta" (Zaltzman, 1994, p. 16).

A autora afirma que, mais do que objeto de satisfação, o filho se tornou para a mãe um objeto de necessidade, o que o caracterizava como tendo uma “função vital" para ela. Na concepção de Zaltzman (1994), isto aponta para a impossibilidade da mãe de sobreviver à eventual ausência ou à perda desse filho, e também para o fato de que o objeto libidinal se transformou em objeto de necessidade. Tal transformação provocaria muita agonia mental e, de acordo com Zaltzman (1994), isto é o que caracteriza casos em que Thanatos, a pulsão de morte, domina o cenário psíquico.

David, o filho da paciente em questão, teve uma infância mais difícil do que os irmãos justamente pelo peso do investimento da mãe. Durante toda a vida, o menino desenvolveu sintomas que se apresentavam, para Zaltzman (1994), como tentativas de separação da mãe, inclusive uma anorexia. Mais velho, David foi diagnosticado com leucemia, motivo que fez a mãe procurar a análise. Durante o período em que estava internado para o tratamento da doença, o menino não quis receber visitas de sua mãe ou mesmo falar com ela, o que caracterizava mais uma e nova tentativa de separação. Para a autora, tal tentativa foi, inclusive, a condição de sobrevivência do adolescente (Zaltzman, 1994).

Portanto, Zaltzman (1994) pensa a pulsão de morte não somente a partir de sua "finalidade mortífera", mas também a partir de suas manifestações úteis 
à vida. De acordo com a autora, "o que marca Thanatos é a carga afetiva que induz ou acompanha o gosto pela mudança, pela errância, pela marginalidade; é o valor da luta que estas mudanças têm contra organizações de vida aprisionantes" (Zaltzman, 1994, p. 34). Isto significa que Eros em excesso pode também ser pensado como patológico, já que em sua busca por síntese, a pulsão de vida pode acabar construindo relações e estruturas totalizantes, uma vez que os laços libidinais buscam a anulação da alteridade (Zaltzman, 1994).

Inclusive, é em função da característica conservadora de Eros, que busca manter as unidades e, assim, aniquilar as diferenças, que Garcia-Roza (2004) afirma que "a verdadeira morte - a morte do desejo, da diferença sobrevém por efeito de Eros e não da pulsão de morte" (p. 137). Parecemos encontrar também em Rosenberg (2003) a ideia de que o excesso de Eros pode construir relações totalizadoras. $\mathrm{O}$ autor fala sobre o efeito que a desintrincação pulsional, que acompanha toda intrincação pulsional, tem sobre a libido. Em sua concepção, este processo deixa a libido diante de um objeto pouco diferenciado, o qual só poderia investir imediata e intensamente. Como resultado, o sujeito apresentaria uma dificuldade de se diferenciar do objeto, sentindo-se, então, invadido pelo mesmo. Neste caso, a excitação do investimento não mediada se tornaria insuportável e resultaria na clivagem do ego.

Desta forma, segundo a lógica de Rosenberg (2003), a clivagem promovida pela ação da pulsão de morte é uma ação secundária e defensiva diante do movimento de uma libido cujos efeitos são insuportáveis. Portanto, a boa relação entre a libido e o objeto necessitaria do aporte da pulsão de morte, uma vez que "é a pulsão de morte que os coloca a uma distância suportável um do outro, tornando, assim, possível, uma elaboração do desejo, como acontece na neurose, evitando a colusão direta entre o desejo e seu objeto" (Rosenberg, 2003, p. 166).

A partir da ideia de que os movimentos propiciados pela pulsão de vida podem também ser tóxicos, a ruptura provocada pela ação da pulsão de morte proporciona a possibilidade de "abrir uma saída onde uma situação crítica desmorona sobre o sujeito e o destina à morte" (De Oliveira \& Winograd, no prelo, p. 24), vindo introduzir a desordem numa constituição aprisionante. No caso da paciente de Zaltzman (1994), a ação da pulsão de morte pôde 
possibilitar, tardiamente, a separação necessária à sobrevivência. Ou seja, em relações totalizantes, onde o espaço para a diferença e para a ausência não pode se dar, a pulsão de morte aparece como protesto vital pela vida. Zaltzman (1994) denomina pulsão anarquista "a exigência destruidora que arruína toda relação fixa" (p. 61), e que seria uma categoria da pulsão de morte. O objetivo é encontrar uma saída vital para uma situação aprisionante, saída que se constitui, ao mesmo tempo, como resistência e protesto, portanto, como "luta contra o aniquilamento" (De Oliveira et al., 2016).

É por esse motivo que não podemos conceber a pulsão de morte somente como o negativo da pulsão de vida (Zaltzman, 1994; De Oliveira et al., 2016), nem somente a partir dos movimentos mortíferos que pode suscitar, uma vez que tal concepção não parece abarcar toda a complexidade e importância do conceito. Portanto, acreditamos ser preciso também compreender as contribuições da pulsão de morte para a vida psíquica, uma vez que esta pulsão permite a criação de novas formas no aparato psíquico (GarciaRoza 1987, 2004; De Oliveira et al., 2016), produz a diferenciação mãe/bebê necessária à própria constituição psíquica (Freud, 1925/2006; Green, 1983/1988, 1993/2010) e, mesmo nos casos em que este processo falha, se apresenta como protesto último e radical em favor da vida (Zaltzman, 1994). 


\section{5 \\ Considerações finais}

A pulsão de morte apresentou a radicalidade à teoria psicanalítica. Pensado a partir do traumático que é efeito de um excesso irruptivo para o qual não há palavras ou significação, este conceito colocou o irrepresentável no centro da questão clínica, uma vez que confrontou Freud (1920/2006) com novas sintomatologias e organizações subjetivas que não podiam ser pensadas simplesmente a partir da lógica da sexualidade, provocando, assim, o questionamento e posterior reconfiguração dos até então principais pilares teóricos: o primeiro dualismo pulsional e a primeira tópica do aparato psíquico (Freud, 1920/2006, 1923/2006). Vimos como o conceito passou por diversas reformulações na teoria freudiana, uma vez que o psicanalista partiu de uma concepção de pulsão de morte como tendência ao inorgânico, detectou sua face destrutiva contra o próprio sujeito e os outros, e por fim definiu-o como relacionado aos processos disjuntivos e à diferenciação interno/externo (Freud, 1925/2006, 1930/2006).

Mas, se o trauma desestruturante, que desorganiza o psiquismo e promove os movimentos de compulsão à repetição, na tentativa de ligação e domínio da energia livre da pulsão de morte, foi o que a princípio fez Freud (1920/2006) pensar na postulação do conceito, pudemos ver que, em outras circunstâncias, como diante de um aparato cujas fronteiras são mais sólidas, ou diante de uma intensidade menor, o excesso pulsional é o que promove, sobretudo, a reorganização do psiquismo e o trabalho no sentido de criação de novas formas. Podemos afirmar, então, que a irrupção representada pela pulsão de morte, que desconstrói os laços e os sentidos estabelecidos, é o que promove o movimento do aparato psíquico, sua reconfiguração e mesmo a construção de novas representações e novos significados, impedindo, assim, que o psiquismo permaneça estacionado nas formas já consolidadas (Garcia-Roza, 1987, 2004). Como vimos em Freud (1923/2006), a pulsão de vida busca estabelecer unidades cada vez maiores. Estas unidades podem, portanto, se caracterizar como totalizantes e, portanto, aprisionantes (Zaltzman, 1994). Sem a ação disjuntiva da pulsão de morte, não é possível desconstruí-las. 
Dessa forma, o irrepresentável que pode desestabilizar o aparato psíquico, é também o que trás a possibilidade de transformação e do novo, podendo se caracterizar como uma potência criativa, uma vez que os desligamentos que a pulsão de morte proporciona podem complexificar o psiquismo (De Oliveira et al, 2016). É a destruição como origem do devir (Spielrein, 1912/2014), destruição necessária para qualquer possibilidade de criação e de mudança. A negatividade da pulsão de morte é, deste modo, possibilidade e mesmo condição da positividade (De Oliveira et al., 2016). Condição também da própria constituição psíquica, ao introduzir a diferença e possibilitar os movimentos de separação na relação mãe/bebê, necessários para a individuação do sujeito e para o estabelecimento dos limites entre o mundo interno e o mundo externo, bem como entre as instâncias que constituem o aparato (Green, 1982/2003).

Como pudemos ver a partir de A Negativa (Freud, 1925/2006) e na teorização de André Green (1983/1988, 1993/2010), ao movimentar o processo de negativação do objeto primário, a pulsão de morte possibilita a criação da estrutura enquadrante que será o espaço psíquico pessoal, solo criativo a partir do qual poderão se construir formações psíquicas como a representação e o pensamento. A negação propiciada pela ação desta pulsão instaura, através do trabalho do negativo, o primeiro limite entre interno e externo, proporcionando, assim, a primeira diferenciação que organiza e desenvolve a estruturação psíquica (Green, 1990, 1993/2010).

Nas palavras de Green (1993/2010), “a conjunção dos aspectos do negativo é, de um lado, o que delimita o possível, de outro lado, o que destrói o possível” (p. 304). Apesar de toda potencialidade criadora que o trabalho do negativo bem sucedido pode instigar, o seu fracasso, resultado da relação com um objeto primário que não permite sua perda e tampouco a diferenciação, promove uma constituição egóica cujos limites são fragilmente definidos, o que significa um sujeito com prejuízos na capacidade representativa e desejante. É inegável que, nesses casos, a intensificação da pulsão de morte provoca efeitos patológicos e intenso sofrimento psíquico, como vimos a partir das defesas radicais de que o psiquismo lança mão quando se vê diante do traumático que ameaça sua integridade egóica. 
No entanto, nos parece interessante ir além dessa potencialidade traumática para enxergar a luta desses sujeitos pela sobrevivência psíquica, batalha na qual a pulsão de morte é chamada, uma vez que "numa relação de forças sem saída, só uma resistência nascida das próprias fontes pulsionais de morte pode afrontar a ameaça de perigo mortal" (Zaltzman, 1994, p. 64). Dessa forma, os efeitos patológicos provocados pela intensificação desta pulsão podem também ser interpretados como a forma última de resistência de um sujeito que se vê diante de uma relação que paralisa todo seu psiquismo. Essa resistência se caracteriza pelo esforço hercúleo de se libertar do objeto primário e, portanto, ficar dele independente, o que possibilitaria a construção dos limites egóicos e da estrutura enquadrante que não puderam ser constituídos num momento precoce.

Dessa forma, apostamos na tentativa de subjetivação desse psiquismo que só pôde se constituir a partir das defesas contra o traumático que, de outra forma, o aniquilaria. Inclusive, concordamos com De Oliveira e Winograd (no prelo), quando afirmam que, tendo o sujeito sobrevivido ao trauma, mesmo que ao desestruturante, está em andamento um processo de subjetivação. Afinal, mesmo diante de uma vivência excessiva com o objeto primário, relação que provocou tamanha desorganização, o psiquismo do sujeito que sobrevive segue “em sua busca incessante por processamento, que se mantém pulsante ainda que encontre um limite, um resto intransponível e impossível de elaborar" (De Oliveira \& Winograd, no prelo, p. 28). Nessa insistência pela vida, a pulsão de morte é, portanto, a resistência e o protesto últimos em sua defesa (Zaltzman, 1994), radicalidade característica desta pulsão, que aqui trabalha para a preservação da vida.

A ideia de que os efeitos patológicos da pulsão de morte apresentados na sintomatologia dos casos limite são resultado de uma tentativa de subjetivação, nos faz apostar numa possibilidade de trabalho que pode dar algum destino para essa energia livre dentro da análise. Desta maneira, apostamos que o analista pode se utilizar da contratransferência para estabelecer uma relação de confiança que ofereça ao analisando pouco integrado uma sustentação no tempo, no espaço e uma continência, o que permitiria o estabelecimento de sua unidade egóica (Winograd, M; Klautau, P; Bezerra JR. B, 2014). 
Portanto, apostamos na possibilidade de ligação do excesso que provoca angústias e sofrimentos tão intensos, ligação que os transformaria em possibilidade de criação e de produção de sentido. Como nos dizem De Oliveira \& Winograd (no prelo), “a favor do processo analítico está o próprio psiquismo" (p. 28), em sua insistente tentativa de subjetivação. 


\section{Referências bibliográficas}

BOKANOWSKI, T. Variações do conceito de traumatismo: traumatismo, traumático, trauma. Revista Brasileira de Psicanálise, v.39, n.1, 27-38p. 2005.

BORGES, G. M. Neurose Traumática. Curitiba: Juruá Editora, 2012, $172 \mathrm{p}$.

CANDI, T. O Aparelho Psíquico de André Green. 1. ed. São Paulo: Escuta, 2010, 341p.

CARDOSO, M. R. A insistência do traumático no espaço psíquico e analítico. In: CARDOSO, M. R; GARCIA, C. Entre o Eu e o Outro: Espaços Fronteiriços. Curitiba: Juruá Editora, 2010, 47-63p.

CAROPRESO, F; SIMANKE, R. T. Compulsão à Repetição: Um Retorno às Origens da Metapsicologia Freudiana. Ágora, Rio de Janeiro, v.IX, n.2, 207-224p. 2006. Disponível em: <http://www.scielo.br/ pdf/agora/v9n2/a04v9n2.pdf.> Acesso em: 17 jul. 2016.

CARVALHO, M. T. P.; VIANA, T. de C. Do Negativo em Freud e Green: contribuições ao estudo dos casos-limite. ALTER - Revista de Estudos Psicanalíticos, v.30, 39-54p. 2012. Disponível em: $<$ http://www.spbsb.org.br/site/images/Novo Alter/2012 2/04MarciaTere zinha.pdf.> Acesso em: 13 mar. 16.

CROMBERG, R. U. A Emergência do Conceito de Pulsão de Morte. In: (Org.). Sabina Spielrein, Uma Pioneira da Psicanálise. 1. ed. São Paulo: 2014. 217-226p.

FIGUEIREDO, L. C; CINTRA, E. U. Lendo André Green: o trabalho do negativo e o paciente limite. In: CARDOSO, M. R. (Org.). Limites. São Paulo: Escuta, 2004. 13-58p.

FIGUEIRÓ, M. C. S. Die Verneinung e a pulsão de morte: algumas considerações. Psychê, São Paulo, ano VI, n. 10, 173-183p. 2002. Disponível em: <http://www.redalyc.org/pdf/307/30701011.pdf.> Acesso em: 8 ago. 2016.

FREUD, S. Projeto para uma psicologia científica (1950 [1895]). In: Edição Standard Brasileira das Obras Psicológicas Completas de Sigmund Freud. vol I. Rio de Janeiro: Imago, 2006. 335-454p.

Carta 52 (1896a). In: Edição Standard Brasileira das Obras Psicológicas Completas de Sigmund Freud. vol I. Rio de Janeiro: Imago, 2006. 281-287p.

A Etiologia da Histeria (1896b). In: Edição

Standard Brasileira das Obras Psicológicas Completas de Sigmund Freud. vol III. Rio de Janeiro: Imago, 2006. 187-215p. Observações Adicionais sobre as Neuropsicoses de Defesa (1896c). In: Edição Standard Brasileira das Obras 
Psicológicas Completas de Sigmund Freud. vol III. Rio de Janeiro: Imago, 2006. 159-215p.

A Interpretação dos Sonhos (I) (1900). In:

Edição

Standard Brasileira das Obras Psicológicas Completas de

Sigmund Freud. vol IV. Rio de Janeiro: Imago, 2006.

Sobre os Sonhos (1900-1901). In:

Edição

Standard Brasileira das Obras Psicológicas Completas de

Sigmund Freud. vol V. Rio de Janeiro: Imago, 2006. 653-700p.

A concepção psicanalítica da perturbação psicogênica da

visão (1910). In:

Edição Standard Brasileira das Obras

Psicológicas Completas de Sigmund Freud. vol XI. Rio de Janeiro: Imago, 2006. 219-227p.

Formulações sobre os dois princípios do funcionamento

mental (1911). In:

Edição Standard Brasileira das Obras

Psicológicas Completas de Sigmund Freud. vol XII. Rio de Janeiro: Imago, 2006. 233-244p.

Recordar, repetir e elaborar (1914a). In: Edição

Standard Brasileira das Obras Psicológicas Completas de Sigmund Freud. vol XII. Rio de Janeiro: Imago, 2006. 163-171p.

Sobre o Narcisismo: uma introdução (1914b). In:

Edição Standard Brasileira das Obras Psicológicas

Completas de Sigmund Freud. vol XIV. Rio de Janeiro: Imago, 2006. 77-113p.

Os Instintos e Suas Vicissitudes (1915). In:

Edição Standard Brasileira das Obras Psicológicas Completas de Sigmund Freud. vol XIV. Rio de Janeiro: Imago, 2006. 117-144p. Além do Princípio de Prazer (1920). In: Edição

Standard Brasileira das Obras Psicológicas Completas de Sigmund Freud. vol XVIII. Rio de Janeiro: Imago, 2006. 13-75p.

O Ego e o ld (1923). In:

Edição Standard

Brasileira das Obras Psicológicas Completas de Sigmund Freud. vol XIX. Rio de Janeiro: Imago, 2006. 15-80p.

A Negativa (1925). In:

Edição Standard Brasileira

das Obras Psicológicas Completas de Sigmund Freud. vol, XIX, Rio de Janeiro: Imago, 2006, 263-269p.

Mal-Estar na Civilização (1930). In:

Edição

Standard Brasileira das Obras Psicológicas Completas de Sigmund Freud. vol XXI. Rio de Janeiro: Imago, 2006. 67-148p.

GARCIA, C. Continuidade e ruptura no processo de constituição psíquica. In: CARDOSO, M. R; GARCIA, C. Entre o Eu e o Outro: Espaços Fronteiriços. Curitiba: Juruá Editora, 2010a, 29-46p

Os estados limites e o trabalho do negativo: uma contribuição de A. Green para a clínica contemporânea. In: CARDOSO, M. R; GARCIA, C. Entre o Eu e o Outro: Espaços Fronteiriços. Curitiba: Juruá Editora, 2010b, 91-101p

GARCIA, C.; DAMOUS, I. O Silêncio no Psiquismo: Uma Manifestação do Trabalho do Negativo Patológico. Cad. Psicanál.-CPRJ, Rio de Janeiro, ano 31, n. 22, 105-115p. 2009. Disponível em: <http://www.cprj.com.br/imagenscadernos/09.O_silencio_no_psiquismo .pdf> Acesso em: 18 ago. 2015. 
GARCIA-ROZA, L. A. Acaso e repetição em psicanálise: uma introdução à teoria das pulsões. Rio de Janeiro: Jorge Zahar, 1987. $128 p$.

Introdução à Metapsicologia Freudiana 3. Rio de Janeiro: Jorge Zahar, 1996. 296p.

O Mal Radical em Freud. 5. ed. Rio de Janeiro: Jorge Zahar, 2004. 166p.

GREEN, A. La Double Limite (1982). In: La Folie Privée. Gallimard, 2003.

Paulo: Escuta, 1988, 302p.

Narcisismo de Vida, Narcisismo de Morte (1983). São

Conferências Brasileiras de André Green: Metapsicologia dos Limites. Rio de Janeiro: Imago Ed., 1990, 209p.

O trabalho do negativo (1993). Porto Alegre: Artmed, 2010.

$313 p$.

La muerte en la vida: Algunos puntos de referencia para la pulsión de muerte. In: Revista de Psicoanálisis, 2001.

Orientações para uma Psicanálise Contemporânea (2002). Rio de Janeiro: Imago, 2008. 373p.

GONDAR, J. Um paradoxo nos sofrimentos narcísicos. In: HERZOG, R, PACHECO-FERREIRA, F. (Org.). De Édipo a Narciso: a clínica e seus dispositivos. Rio de Janeiro: Cia de Freud, 2014. 119-134p.

HYPPOLITE, J. Comentário Falado Sobre a Verneinung de Freud. In: LACAN, J. Escritos. Rio de Janeiro: Jorge Zahar Editor, 1998, 893902p.

KNOBLOCH, F. O tempo do traumático. São Paulo: EDUC, 1998. 160p.

LAPLANCHE e PONTALIS. Vocabulário da Psicanálise. São Paulo: Martins Fontes, 1997. 576p.

LEJARRAGA, A. L. O Trauma e seus Destinos. Rio de Janeiro: REVINTER, 1996. 101p.

MEZAN, R. Freud: A Trama dos Conceitos. São Paulo: Editora Perspectiva, 2013. 350p.

DE OLIVEIRA, M; WINOGRAD, M; FORTES, I. A pulsão de morte contra a pulsão de morte. In: Piscol. Clin. vol.28 no.2 Rio de Janeiro, 10p. $2016 . \quad$ Disponível em: $<$ http://pepsic.bvsalud.org/scielo.php?script=sci arttext\&PI $\quad d=S 0103-$ 56652016000200005.> Acesso em: 10 out. 2016.

DE OLIVEIRA, M. T.; WINOGRAD, M. A Dupla Potencialidade do Irrepresentável e a Negatividade Necessária: Trauma e Pulsão de Morte. 31p (no prelo)

ROSENBERG, B. Pulsão de Morte e Intrincação Pulsional ou a Pulsão de Morte na Construção do Objeto e o Aparelho Psíquico ou a Pulsão de Morte e a Dimensão Masoquista da Existência. In: Masoquismo Mortífero e Masoquismo Guardião da Vida. São Paulo: Escuta, 2003. 157-202p.

ROUDINESCO, E.; PLON, M. Dicionário de psicanálise. Rio de Janeiro: Jorge Zahar. 874p. 
SPIELREIN, S. A Destruição como Origem do Devir, 1912. In: CROMBERG, R. U. (Org.). Sabina Spielrein, Uma Pioneira da Psicanálise. São Paulo: 2014, 227-277p.

WINOGRAD, M. Freud e a Fábrica da Alma. Curitiba: Editora Appris, 2013. 260p.

WINOGRAD, M; KLAUTAU, P; BEZERRA JR. B. Normatividade e plasticidade: algumas considerações sobre a clínica psicanalítica com pacientes neurológicos. Revista Mal-Estar e Subjetividade, Fortaleza, IX, 551-574p. 2009.2 Disponível em: $<$ http://pepsic.bvsalud.org/pdf/malestar/v9n2/08.pdf.> Acesso em: 18 out. 2014.

ZALTZLMAN, N. A Pulsão Anarquista, São Paulo: Escuta, 1994. 97p. 